\title{
The impact of macroeconomics factors on real exchange rate in Latin America: A dynamic panel data analysis
}

\author{
Carlos Chavez*
}

\begin{abstract}
This paper studies the determinants of the real exchange rate using macroeconomic variables, and whether they can predict it. A panel data is used, which estimator is system GMM that allows controlling the endogeneity of the variables. In turn, we transformed the variables with forward orthogonal deviations (FOD) and first difference (FD), which allows us to eliminate unobserved effects that are invariant in time. To check the robustness of the estimates, different periods were used, from 1980-2019, 2000-2019 and 2010-2019. For the period 1980-2019, it is found that the past values of the real exchange rate, the current values of inflation, economic growth, fiscal and monetary policy have positive effects on the current values of the real exchange rate, while the money supply and the terms of trade have negative impacts on the real exchange rate. For the period 2000-2019, we had similar results and for the period 2010-2019, we found that economic growth has negative impacts on the real exchange rate. It is also presented the Arellano-Bond test and the Sargan test to estimate model over-identification. Using the Pedroni test, we estimated the cointegration of the variables with respect to the real exchange rate, finding cointegration with inflation in the long run. The originality of this paper is that we focused on Latin American countries, analyzing short-term relationships with the System GMM estimator and long-term relationships with the Pedroni Test.
\end{abstract}

Keywords: Real exchange rate, System GMM, Macroeconomic factors, Developing countries.

\section{Resumen}

Este artículo estudia los determinantes del tipo de cambio real utilizando variables macroeconómicas y si estas pueden predecirlo. Se utilizó un panel de datos cuyo estimador es el sistema GMM que permite controlar la endogeneidad de las variables. A su vez, se transformaron las variables con desviaciones ortogonales hacia adelante (FOD) y la segunda es primera diferencia (FD), que nos permite eliminar efectos no observados que son invariantes en el tiempo. Para comprobar la solidez de las estimaciones, se utilizaron diferentes períodos, de 1980-2019, 2000-2019 y 2010-2019. Para el período 1980-2019, se encontró que los valores pasados del tipo de cambio real, los valores actuales de inflación, crecimiento económico, política fiscal y monetaria tienen efectos positivos sobre los valores actuales del tipo de cambio real, mientras que la oferta monetaria y los términos de intercambio tienen impactos negativos sobre el tipo de cambio real. Para el período 2000-2019, obtuvimos resultados similares y para el período 2010-2019, encontramos que el crecimiento económico tiene impactos negativos en el tipo de cambio real. También se utilizó la prueba de Arellano-Bond y la prueba de Sargan para estimar la sobreidentificación del modelo. Utilizando la prueba de Pedroni, estimamos la cointegración de las variables con respecto al tipo de cambio real, encontrando cointegración con la inflación en el largo plazo. La originalidad de este artículo radica en que se enfoca en los países de América Latina, analizando las relaciones de corto plazo con el estimador System GMM y las relaciones de largo plazo con el Test Pedroni.

Keywords: Tipo de cambio real, Sistema GMM, factors microeconómicos, países en desarrollo.

JEL classification: F17, F41, F47, F31

\footnotetext{
* Research Associate at Universidad Nacional Mayor de San Marcos (Lima-Peru). Research Assistant, International Monetary Fund. Email: carlos.chavez2@unmsm.edu.pe. Received: April, 24 ${ }^{\text {th }}$ 2020; modifications: December, $3^{\text {rd }}$ 2020; accepted: December, $21^{\text {st }} 2020$.
} 
Carlos Chávez

The impact of macroeconomics factors on real exchange rate in Latin America: A dynamic panel data analysis

\section{Introduction}

This paper studies the macroeconomic variables that can explain future variations in the real exchange rate, focused on Latin American countries. The main reason for this research is that the real exchange rate is an indicator that can measure macroeconomic welfare among countries. Besides, the real exchange rate can be seen as a measure of competitiveness due to its effects on net exports, of the cost of living among countries, or also as a measure of dependency among countries (Mesquita et al., 2017).

The sample is comprised by 14 countries with 39 years of data availability from 1980 to 2019. The methodology used is a data panel with System GMM as estimator, and it is described in section 3. We control for periods of high inflation, such as Peru in 1988-1990, currency crisis in 1999-2000 and financial crisis 2008-2010, by adding dummy variables. This paper contributes to the literature because it allows explaining movements in the real exchange rate from macroeconomic variables in countries suffering from constant inflation such as Latin American countries. In turn, based on Nikolaou (2006), we add lagging variables because they have dynamic behavior, which means that their past movements can explain their current movements. Considering all the periods of the regression, we find that the lagged values of the real exchange rate have a great positive influence on the current value of that variable, in that vein, we also find that the inflation, GDP and interest rate have positive impacts on the real exchange rate. On the other hand, monetary supply and the terms of trade have negative impacts on the real exchange rate, and the public spending have different effects considering different periods. The results in this paper are consistent with the literature and the empirical evidence, except for public spending. Furtermore, the Pedroni test is applied, finding that the inflation has long-term relationship with the real exchange rate.

The paper is developed as follows: The following section makes a review of the supporting literature, considering the reasons for the chosen variables and their possible effects on the real exchange rate. Section 3 describes the economic methodology used to estimate the effects of these variables on the real exchange rate. Section 4 shows the results and interpretations, and section 5 presents the conclusions of this paper.

\section{Literature Review}

International macroeconomic theory on the real exchange rate began in the 1970s. Frenkel (1976) developed a model for determining the exchange rate from an asset view, which included the money supply and inflation. This author emphasizes the importance of the expectations to determine the real exchange rate. In relation to that research, Dornbusch and Fischer (1980) develop a model in which they integrate the role of relative prices, expectations and asset markets to take into account the relationship between the exchange rate and the current account. They emphasize the importance of expectations for short-term behavior in the exchange rate. Monetary changes in models where asset markets move rapidly relative to the goods market lead to real exchange rate depreciation. Dornbusch (1980) develops a model in which inflation is related to the real exchange rate and the real interest rate. Dornbusch (1987) develops

a model on the relationship between exchange rate determination and wage effects. Other papers that have contributed to the development of the theoretical framework in the determination of the real exchange rate are Messe and Roggof (1988) and Roggof (2003). Additionally, Devereux (1997) reviews the theory and evidence of the real exchange rate. 
In an open economy context, imbalances process can occur, which is when the real exchange rate deviates from the equilibrium real exchange rate. An undervaluation (overvaluation) occurs when a depreciation (appreciation) of the real exchange rate relative to the equilibrium real exchange rate takes place. Edwards (1987) researches about these imbalances through domestic and external real exchange rate determinants; these imbalances affect the economy. Cottani et al. (1990) examine the behavior and performance of the real exchange rate for less developed countries through the imbalances and how these imbalances affect economic growth. His model aggregates terms of trade, international transfer, world real interest rate, trade policies, exchange and capital controls, government expenditure and technological progress. Ghura and Grenees (1993) study the effects of macroeconomic performance on the real exchange rate in SubSaharan Africa, following Edwards' model of determination (1987). To do so, it considers GDP per capita, net exports with respect to GDP, domestic savings with respect to GDP and Investment with respect to GDP, finding negative effects of real exchange rate imbalances on economic growth. Razin and Coolins (1997) construct an indicator of Real Exchange Rate imbalances for developing and developed countries by finding non-linear relationships between economic growth and such imbalances, an undervaluation being associated with faster growth. Balázs and Amina (2003) estimate the effects of exchange rate balances on economic growth for countries in Eastern Europe.

Due to the implications of the movements of the real exchange rate on its equilibrium real exchange rate, it increases the importance of analyzing this variable and the variables that determine it. Policymakers can make predictions of this variable from other endogenous variables in a context of undervaluation of the currency, high inflation or a fall in economic growth. Jongwanich (2011) studies the relationship between real exchange rate imbalances in a context of currency crisis for the case of Thailand in the period 1997-1998. This analysis finds that a persistent overvaluation of the real exchange rate from 1991 until the onset of the crisis in 1997, too much short-term capital inflow and an expansive fiscal policy could cause the currency crisis in that country. This is in line with other papers such as Edwards (1999), Goldstein (1998) and Athukorala and Warr (2002). On the other hand, research carried out by McKinnon (1998) and Radelet and Sach (1998) find no evidence that persistent overvaluation leads to a currency crisis. Other studies that focus on the effects of the real exchange rate is Branson and Love (1998), that use a computable general equilibrium (CGE) model to estimate the effects of an exchange rate appreciation on employment in the manufacturing sector at a disaggregated level. Dooley and Isar (1987) study the links between changes in the exchange rate on physical capital flows in different countries. Balassa (1964) and Samuelson (1964) study what was later called the Balassa-Samuelson effect, where a high real exchange rate can generate more profits in internationally tradable sectors. Furthermore, Isard et al. (1987) analyze this effect to test the links between economic growth and the real exchange rate. Later, Isard (2007) reviews the methodologies used to find an equilibrium real exchange rate. Mussa (1986) finds that the exchange rate is extremely volatile for U.S dollar and can move as random walk.

The variables considered for the model are inflation, gross domestic product (GDP), monetary policy interest rate, public expenditure, money supply, and terms of trade. Regarding the first variable, inflation, the consumer price index is used, $c p i_{i, t}$. There is a large literature about the relationship between inflation and the real exchange rate. In a new Keynesian theoretical framework, the real exchange rate is negatively affected by the domestic price level. Assuming that a domestic price growth occurs, i.e., a rise in domestic inflation makes the economy less competitive, because the prices of goods in the tradable sector will increase, which will harm the economy in international trade. The increase of the domestic price causes 
The impact of macroeconomics factors on real exchange rate in Latin America: A dynamic panel data analysis

a fall of the real exchange rate, in other words, a real appreciation. This is what is called a pass-through effect which refers to how much the price of tradable goods in local currency changes with variations in the foreign currency in terms of local currency. The pass-through effect seeks to measure how much of the change in the exchange rate is transmitted to domestic prices in terms of local currency. Mann (1986) notes that this effect can be found in a variety of industries. At the empirical level, a consensus on the results can be found, i.e., there is a negative relationship between inflation and the exchange rate. Andrew \& Dollery (1980) estimate the pass-through effects in the automobile industry in Australia, which are dependent on the price-demand elasticity. Goldberg and Knetter (1997) note that market power in certain markets may be associated with the degree of power of this effect on local price. Menon (1995) reviews both the empirical and theoretical literature on the pass-through effect of the exchange rate, finding that the effect may vary depending on the methodology that has been used to estimate the effect. Kim (1998) argues that positive impacts of the exchange rate can be found on the US Consumer Price Index; while Hufner and Schroder (2002) use the Harmonized Index of Consumer Price (HICP) to estimate passthrough effects of exchange rate changes on domestic prices for the euro area. They found that a fall in the effective exchange rate index tends to increase by $0.5 \%$ after 12 months. Antoniades and Zaniboni (2016) study this effect using scanner data on goods sold by 1041 outlets in the UAE between 2006 and 2010, finding negative effects of the exchange rate on inflation. Campa and Goldberg (2008) use a time series and cross-section data to find sensitivities between the retail price and the exchange rate, realizing that the effect may have fallen on the import price level, but has mixed effects on the type of good traded. Asad et al. (2012) find that the real exchange rate has negative impacts on inflation in Pakistan. Kuijis (1998), using a long-term co-integration model, refers to the non-significant impacts of the real exchange rate on inflation in Nigeria. Clarida and Waldman (2007) argue that impacts can be heterogeneous as the exchange rate rises and falls on inflation. Therefore, as shown in this review of the literature, there is clear empirical evidence that there is a negative relationship between these two variables.

The second variable used is the gross domestic product, $g d p_{i, t}$, which has effects on other variables such as private consumption, private investment, public expenditure and net exports. Following a new Keynesian theoretical framework, the transmission mechanism should be: a rise in gross domestic product generates a rise in the demand of money, which would provoke an increase of local inflation, hence, this increase would provoke a fall of the real exchange rate. There is a wide literature that has tried to test the relations between the real exchange rate and economic growth. In this context, Rodrik (2008) states that undervaluation of the real exchange rate can have positive effects on economic growth. Habib et al. (2016) find that an appreciation of the real exchange rate reduces real gross domestic product using a sample of 150 countries and a period of 40 years; similar results for Bangladesh are presented by Razzaque et al. (2012). Guzman et al. (2018) point out that a stable and competitive real exchange rate policy can correct externalities and other market failures; this can lead to a greater increase in economic growth due to a spillover effect among various sectors of the economy. McCandless and Weber (1995) find evidence of long-term relationships between economic growth, inflation and monetary aggregates.

The third variable used is the monetary policy interest rate, $i_{i, t}$, which can impact the real exchange rate. On this relationship there is a rich new Keynesian theoretical framework. From a monetary approach, Mcdonald and Taylor (1993) try to predict the exchange rate and find a long-term equilibrium. They use monthly data from the deutsche mark-U.S. dollar exchange rate, using the Campbell-Shiller technique and adding variables such as money supply, inflation and interest rate. Clárida et al. (1998) point out that the exchange rate can influence the monetary policy interest rate regardless of the information they 
contain about inflation and the GDP. They use the real exchange rate, among other variables to estimate the behavior of the monetary policy interest rate. Clárida (2001) uses a structural VAR to estimate the dynamic effects of the monetary policy on variables such as the exchange rate, inflation, and GDP. A shock of the monetary policy will tend to depreciate, increase, the real exchange rate. Woodford (2003) points out that the effects of a monetary policy in the economy will depend on the expectations of the short-term interest rate, the yields of the bonds, the price of the assets and the exchange rate. Zettelmeyer (2000) studies the impacts of monetary policy on the real exchange rate for Australia, Canada and New Zealand during the 1990s. Through a Self-Regressive Vector model, the author finds that a contractionary shock will appreciate (reduce) the exchange rate. Cushman and Zha (1997), assuming a structural model among the contemporary variables, encounter an appreciation in the exchange rate before a monetary policy shock for Canada, the same findings are present in Clarida and Gertler (1997) for Germany. Grili and Roubini (1995) refer to the fact that for several countries, except the United States, the direction and significance of the exchange rate in the face of a monetary policy shock is often not robust if VAR with identifying assumptions is used. Black (1984) studies the relationship between the exchange rate and monetary policy for ten industrial countries, including the price of domestic and foreign goods, foreign sources of credit to the domestic economy, foreign interest rate, lending rate, and savings rate. Einchenbum and Evans (1995) find that a monetary policy shock appreciates the exchange rate for the United States, they use the ratio of unborrowed reserves to total reserves in terms of natural logarithm as a proxy for the exchange rate. Other papers that find negative effects of the monetary policy at the exchange rate are Taylor (2001) and, Gagnon and Ihrig (2004).

Public expenditure, public $_{t}$, is the fourth variable included in the model. At a theoretical level there are not many developments on the relationship between these two variables. However, following a New Keynesian theoretical framework, we would expect that a fiscal policy shock opens two channels. On the one hand, the expansion of the aggregate demand, increasing the level of domestic prices, and, therefore, reducing the exchange rate. On the other hand, the increase of the interest rate, which causes an inflow of foreign capital, strengthening the currency and therefore generating an appreciation of the exchange rate. In other types of theoretical frameworks, such as the Redux Model proposed by Obstfeld and Rogoff (1995), who use a rational agent model, Di Giorgio et al. (2015) show that an exchange rate can appreciate in the face of positive public expenditure shocks. Ganelli (2005) points out that if government consumption is completely spent on domestic goods, the exchange rate may be unaffected by this expansion, due to trade-offs between increased spending and increased taxes.

Besides, Corsetti and Presenti (2001), develop a DSGE model for open economies in which an expansion of fiscal policy leads to an appreciation of the exchange rate. At the level of empirical evidence, there are mixed results, for example, Kim and Roubini (2008) for the case of the United States and using a model of auto-regressive vectors, find that a fiscal policy shock tends to improve the current account and depreciate the real exchange rate, in contrast to what the theoretical models predict. Monacelli and Pertti (2010), using autoregressive vectors for four OECD countries, find that a fiscal policy shock tends to depreciate the real exchange rate and put the trade balance in deficit. Basu and Kollman (2013) note that an exchange rate depreciation can occur from the interaction between risk-sharing conditions and the effect of a positive supply of government purchases. Di Giorgi and Nisticó (2017) elaborate a DSGE model with non-Ricardian households and with productive government purchases, finding that a public expenditure shock causes the real exchange rate to depreciate. Enders et al. (2011) find that the real exchange rate tends to depreciate in the face of a public spending shock, using advanced countries as a 
The impact of macroeconomics factors on real exchange rate in Latin America: A dynamic panel data analysis

sample. The same conclusion is reached by Rayn et al. (2012). In addition, Bouakez and Eyquem (2012) encounter that an unexpected increase in public spending will cause depreciations in the real exchange rate, and Penati (1986) develops a theoretical model in which he finds that an expansion of public spending causes real depreciations. Chatterjee and Mursagulov (2012) state that the impact of public spend has U-shape, the path created for the first shock can be reversed for the variables as sectoral composition, financing policy and etc. Miyamoto et al. (2016) present that for developing countries, a shock in public spend cause depreciation on the exchange rate. On the other hand, Beetsna and Giuliodori (2011) find that a government spending shock tends to appreciate the real exchange rate with some lags using a structural self-restraining vector model.

The fifth variable used in this model is the money supply, $m_{i, t}$. Macdonald and Taylor (1991), using a Johansen co-integration model through a self-regressive vector model for Germany, Japan, and the United Kingdom, find that there is a long-term relationship between the money supply and the real exchange rate. Cornell (1982), testing a joint hypothesis about the effects of announcements of a money supply shock on the interest rate and the exchange rate, state that an unexpected announcement can appreciate the real exchange rate. Frankel (1976) studies in a flexible price monetary model the effects of a money supply shock on the German Mark - US Dollar exchange rate during the period of hyperinflation in Germany in the 1920s, finding that these shocks tended to appreciate the exchange rate. Razzak and Grennes (1997) present evidence of positive co-integration between the money supply and the exchange rate in the long term. McNown and Wallace (1994) study the effects of a monetary shock in countries with high inflation such as Argentina, Chile and Israel, finding strong positive effects on the exchange rate. Other author, such as Taylor and Peel (200) find a co-integration using a static regression, and Maitra (2010) studies the causality between money supply and exchange rate for Sri Lanka using an error correction model. The latter finds that lagging values of up to 9 months of money supply cause a depreciation in the exchange rate. Wasserfallen and Kursteiner (1993) research the short-term effects of a money supply shock on the interest rate and the exchange rate for Switzerland, finding that the exchange rate does not systematically react to a money supply shock. However, the effect depends on the time period considered. Husted and Kitchen (1985) find that a jump in the money supply give to appreciation of the exchange rate. Kohlscheen (2011) find that monetary policy shock can appreciations of exchange rate for Brazil, Mexico and Chile.

The sixth and last variable we include in the model is the terms of trade, trade $e_{i, t}$, which is the difference between exports and imports as a percentage of GDP. Mendoza (1995) elaborated a model of intertemporal equilibrium of three sectors for several countries, in which he found that a shock of the terms of exchange could explain up to $60 \%$ of the variability of the exchange rate. Broda (2002) studies the relationships between terms of trade and exchange rate regimes for 75 developing countries, finding that terms of trade shocks differ systematically between exchange rate regimes. In fixed regimes, a termof-trade shock tends to depreciate the exchange rate gently, while in flexible regimes, it depreciates immediately. Blundell-Wignall et al. (1993) find that a 10\% rise in the terms of trade causes an $8 \%$ appreciation of the real exchange rate, Koya and Orden (1994) state that the terms of trade and the exchange rate co-integrate in the long run for New Zealand and Australia. Similar results are found by Gruen and Wilkinson (1994). Additionally, Gruen and Swift (2004) study the relationship between exchange rate changes and consider the terms of trade as endogenous for a small economy. De Gregorio and Wolf (1994) study the relationships between terms of trade, productivity and the real exchange rate for 14 OECD countries finding that a terms of trade shock induces real appreciation of the real exchange 
rate. Chen and Roggof (2003) provide similar results. Other research conducted by Isard (2007) used the term of trade as explicatory variable for creates equilibrium models on real exchange rate; Coudert et al. (2015) find causality and long-run relations between these variables; and Choudhri et al. (2010) argue that the real exchange rate can appreciate in response to an increase in term of trade.

\section{Methodology}

As an empirical strategy, we use system GMM in a Dynamic Data Panel proposed by Arellano and Bond (1991). The main reason for using this econometric model is because it allows us to deal with potentially endogenous variables, as they have been described in the previous section. The sample is comprised by 14 countries, with data available for 39 periods starting from 1980 to 2019, because this estimator has better results when the number of $\mathrm{N}$ individuals (countries) is large and the number of observations, $\mathrm{T}$ tends to be small, see Benito et al. (2018). We added two additional estimates considering the periods 2000-2019 and 2010-2019. The Arellano-Bond autocorrelation test was applied to these regressions in order to control for the absence of autocorrelation between the variables with respect to at least the second previous period. We also apply the Sargan test to see whether the variables were over-identified, considering that there is a large number of periods available. To check that there is serial correlation, that is, that the endogenous variables are correlated with the error, we transform them with two technique. The first is called First Difference (FD) and the second Forward Orthogonal Deviations (FOD). We test that there is no unit root, that is, that the variables are stationary by applying the Dickey-Fuller Augmented test for each country and Im-Pesaran-Shin in the form of panel data. Finally, to test the cointegration of the variables the Pedroni test was used.

\section{Empirical strategies}

The model develops as follows:

$$
Y_{i, t}=\sum_{0}^{P=2} A_{P} X_{i, t-P}+\sum_{1}^{P=2} B_{P} Y_{i, t-P}+\eta_{i}+\epsilon_{i, t}
$$

Where $Y_{i t}$ is the variable we are trying to explain, in this case the real exchange rate. $A_{P}$ and $B_{P}$ are the matrices that contain the coefficients of the model. $X_{i, t-P}$ is the vector of endogenous variables included in the model to explain the real exchange rate. This vector is $\left[c p i_{i, t-P}, g d p_{i, t-P}\right.$, public $_{i, t-P}, i_{i, t-P}, m_{i, t-p}$, trade $\left._{i, t-p}\right] . Y_{i, t-P}$ are the lagged values of the real exchange rate. $\eta_{i}$ are the unobserved effects invariant in time, and $\epsilon_{i, t}$ is the error term.

The model as presented in equation (1) would be biasing the estimates due to the presence of $\eta_{i}$, since $v_{i}=\eta_{i}+\epsilon_{i, t}$ could be correlated with $Y_{i, t}$ or $X_{i, t-P}$, i.e., $\left(v_{i} \mid Y_{i, t}, X_{i, t-P}\right) \neq 0$. As it was mentioned, the first technique used is First Difference (FD), which consists in subtracting the past value from the present value, i.e. $\Delta Y_{i, t}=Y_{i, t}-Y_{i, t-1}$, where $\Delta$ is the first difference operator, then equation(1) is transformed into:

$$
\Delta Y_{i, t}=\sum_{0}^{P=2} A_{P} \Delta X_{i, t-P}+\sum_{1}^{P=2} B_{P} \Delta Y_{i, t-P}+\Delta \epsilon_{i, t}(2)
$$


The impact of macroeconomics factors on real exchange rate in Latin America: A dynamic panel data analysis

While first difference eliminates the effects of not observed invariant in time, still can arise the presence of serial correlation. This occurs when the dependent variable and error term can be correlated, $\left(\Delta Y_{i, t-P} \Delta \epsilon_{i, t}\right) \neq 0$, by the lack of orthogonality, as Hujer et al. (2005) and Chudik and Pesaran (2015) point out, the estimator system GMM would become inconsistent with this lack of orthogonality. Therefore, we add the second transformation technique called forward orthogonal deviations (FOD) that was proposed by Arellano and Bover (1995). This transformation consists of subtracting the average of all future available observations, $\nabla Y_{i, t+1}=c_{i, t}\left(Y_{i, t}-\frac{\sum_{t=1}^{T} Y_{i, t+1}}{T_{i, t}}\right)$, where $T_{i, t}$ is the number of observations for each country and $c_{i, t}$ is the scale factor equal to $\sqrt{\frac{T_{i, t}}{T_{i, t}+1}}$. This scale factor allow that the variables get an independent and identical distribution, minimizing the loss of information and also serve to drop the finite sample bias and enable asymptotic efficiency gains but can generate bias results because increases the number of instruments. For this reason, we check the results with sizes and tests and used the Windmeijer (2005) methodology that serve as finite sample correction. The new estimation is presented as follow:

$$
\nabla Y_{i, t+1}=\sum_{p=0}^{P=2} A_{P} \nabla X_{i, t+p}+\sum_{p=1}^{P=2} B_{P} \nabla Y_{i, t+1}+\nabla \epsilon_{i, t+1}
$$

Following Hayawaka (2009), and applying FOD, we get a better performance than using FD when T is larger. This methodology was proposed by Blundell and Bond (1998). Roodman (2006) reviews and compares all the above methodologies. This estimator has been used by papers from different economic areas such as Acemoglu et al. (2008), Bobba and Coviello (2007) and Heid et al. (2012). All regressions are presented using robust standard errors. We applied the Sargan test and reported in the tables the pvalues with null hypothesis with overidentification. The Arellano-Bond test was also used to test the autocorrelation mainly in order 2. We developed the Pedroni test to see the long-term relationship between the explanatory variables and the exchange rate. This test was developed by Pedroni (1999, 2004), who test the null hypothesis of non-cointegration for non-stationary variables. The methodology is to test the degree of cointegration of the regression residues. For this reason, we apply the level test in terms of natural logarithm, and the Dynamic Last Square as an estimator proposed that allows testing non-cointegration between variables. For more details about its implementation, see Neal (2014). The interpretation is followed by Baltagi (2013), if v-statistic is positive, we can reject the null hypothesis of non-cointegration. The results are presented in the following section.

\section{Results}

Table 1 reports the estimation results for equation 2 and 3 with a period of 1980-2018, using FD and FOD, with both a simple GMM estimator and system GMM estimator. 
Table 1: Estimations for 1980-2019

\begin{tabular}{|c|c|c|c|c|c|c|c|}
\hline Variables & $\begin{array}{c}\text { FD- } \\
\text { GMM }\end{array}$ & $\begin{array}{c}\text { SYS-FD- } \\
\text { GMM }\end{array}$ & $\begin{array}{l}\text { SYS-FD- } \\
\text { GMM (-1) }\end{array}$ & Variables & $\begin{array}{l}\text { FOD- } \\
\text { GMM }\end{array}$ & $\begin{array}{l}\text { SYS-FOD- } \\
\text { GMM }\end{array}$ & $\begin{array}{l}\text { SYS-FOD- } \\
\text { GMM (-2) }\end{array}$ \\
\hline $\begin{array}{c}\Delta q_{i, t} \\
\text { L1. } \\
\text { L2. }\end{array}$ & $\begin{array}{c}0.271^{*} \\
0.012\end{array}$ & $0.183^{* * *}$ & $0.209 * * *$ & $\begin{array}{c}\nabla q_{i, t} \\
\mathrm{~L} 1 . \\
\mathrm{L} 2 .\end{array}$ & $\begin{array}{c}0.751^{* * *} \\
-0.040\end{array}$ & $0.705^{* * *}$ & $\begin{array}{c}0.741^{* * *} \\
0.008\end{array}$ \\
\hline$\Delta \operatorname{cpi}_{i, t}$ & 0.077 & $0.020 *$ & $0.084 * *$ & $\nabla c p i_{i, t}$ & -0.061 & $0.079 * * *$ & $0.748^{* * *}$ \\
\hline L1. & -0.071 & & $-0.067 *$ & L1. & $0.551^{*}$ & & $-0.683^{* * *}$ \\
\hline L2. & 0.002 & & & L2. & $-0.489 * *$ & & -0.024 \\
\hline$\Delta g d p_{i, t}$ & 0.422 & $0.375^{* * *}$ & $0.349 * *$ & $\nabla g d p_{i, t}$ & $0.792^{* * *}$ & 0.015 & $0.768^{* * *}$ \\
\hline L1. & -0.013 & & 0.101 & L1. & $-0.502 *$ & & $-0.741 * * *$ \\
\hline $\mathrm{L} 2$. & -0.054 & & & $\mathrm{~L} 2$. & -0.188 & & -0.201 \\
\hline$\Delta i_{i, t}$ & 0.008 & 0.011 & -0.006 & $\nabla i_{i, t}$ & $0.000 * * *$ & $0.000^{* * *}$ & $0.000 * * *$ \\
\hline L1. & -0.011 & & -0.002 & L1. & 0.000 & & $-0.000 * *$ \\
\hline $\mathrm{L} 2$. & 0.01 & & & $\mathrm{~L} 2$. & 0.000 & & -0.000 \\
\hline$\Delta g o v_{i, t}$ & 0.107 & $0.086^{*}$ & $0.095 *$ & $\nabla g o v_{i, t}$ & $0.185^{* * *}$ & $0.053^{* *}$ & $0.239 * * *$ \\
\hline L1. & $-0.089 *$ & & -0.053 & L1. & -0.076 & & $-0.190^{* * *}$ \\
\hline $\mathrm{L} 2$. & -0.011 & & & $\mathrm{~L} 2$. & -0.048 & & $-0.111 *$ \\
\hline$\Delta m_{i, t}$ & $-0.078^{*}$ & $-0.085^{* * *}$ & $-0.096 * * *$ & $\nabla m_{i, t}$ & -0.035 & $-0.091 * * *$ & -0.017 \\
\hline L1. & -0.035 & & -0.020 & L1. & $-0.102 *$ & & $-0.063^{* *}$ \\
\hline $\mathrm{L} 2$. & $0.054 *$ & & & $\mathrm{~L} 2$. & 0.051 & & $0.074 *$ \\
\hline$\Delta$ trade $_{i, t}$ & -0.17 & $-0.100^{* *}$ & $-0.103^{* *}$ & $\nabla_{\text {trade }}, t$ & $-0.187 * * *$ & $-0.076 * * *$ & $-0.217 * * *$ \\
\hline L1. & $\begin{array}{c}0.11^{* *} \\
*\end{array}$ & & $0.088^{* *}$ & L1. & $0.141^{* * *}$ & & $0.174 * * *$ \\
\hline L2. & 0.065 & & & L2. & 0.025 & & 0.000 \\
\hline year1985 & -0.015 & -0.012 & -0.019 & & -0.203 & $-4.198 * * *$ & $-2.320^{*}$ \\
\hline year1987 & 0.006 & 0.006 & 0.001 & & -0.731 & $-2.875^{* *}$ & -1.880 \\
\hline year1992 & 0.022 & $0.036^{*}$ & 0.029 & & 1.168 & 1.680 & 1.063 \\
\hline year1995 & -0.02 & -0.018 & -0.018 & & -0.239 & 0.657 & -1.265 \\
\hline year2003 & $-0.03 * *$ & $-0.028 * *$ & $-0.028^{*}$ & & -1.174 & $-2.959 * * *$ & $-1.968^{*}$ \\
\hline year2006 & 0.001 & 0.018 & 0.01 & & 0.316 & 1.021 & 0.879 \\
\hline year2009 & 0.013 & 0.013 & 0.018 & & -0.553 & 1.145 & 0.665 \\
\hline $\mathrm{N}$ & 430 & 416 & 416 & & 427 & 413 & 448 \\
\hline
\end{tabular}

The results show that past values of the real exchange rate have a positive and significant impact on current values of the real exchange rate. The current values of inflation, gross domestic product, the interest rate and public spending have positive impacts on the current values of the real exchange rate. While the current values of the money supply and the terms of trade have negative impacts on the current values of the real exchange rate. Table 2 shows the applied tests already mentioned above, Arellano-Bond and Sargan test. 
Carlos Chávez

The impact of macroeconomics factors on real exchange rate in Latin America: A dynamic panel data analysis

Table 2: Testing overidentifying

\begin{tabular}{|c|c|c|c|c|c|c|}
\hline \multicolumn{7}{|c|}{ Test for period 1980-2018 } \\
\hline Test & \multicolumn{2}{|c|}{ FD-GMM } & \multicolumn{2}{|c|}{ SYS-FD-GMM } & \multicolumn{2}{|c|}{ SYS-FD-GMM(-1) } \\
\hline $\begin{array}{c}\text { Arellano-Bond } \\
\text { test } \mathrm{AR}(1)\end{array}$ & $z=-2.25$ & $\operatorname{Pr}>z=0.03$ & $z=-2.68$ & $\operatorname{Pr}>z=0.01$ & $z=-2.62$ & $\operatorname{Pr}>z=0.01$ \\
\hline $\begin{array}{c}\text { Arellano-Bond } \\
\text { test } \operatorname{AR}(2)\end{array}$ & $z=-0.61$ & $\begin{array}{l}\operatorname{Pr}>z \\
=0.544\end{array}$ & $z=-1.24$ & $\operatorname{Pr}>z=0.22$ & $z=-1.01$ & $\operatorname{Pr}>z=0.31$ \\
\hline Sargan Test & $\begin{array}{c}\text { Chi } 2(246)=427 \\
38\end{array}$ & Prob $>_{z}=0.00$ & $\begin{array}{c}\text { Chi } 2(246)=427 . \\
38\end{array}$ & Prob $>_{z}=0.00$ & Chi2(667) $=89.17$ & Prob $>_{z}=0.00$ \\
\hline Test & \multicolumn{2}{|c|}{ FOD-GMM } & \multicolumn{2}{|c|}{ SYS-FOD-GMM } & \multicolumn{2}{|c|}{ SYS-FOD-GMM(-1) } \\
\hline $\begin{array}{l}\text { Arellano-Bond } \\
\text { test } \operatorname{AR}(1)\end{array}$ & . & . & $z=-2.52$ & $\operatorname{Pr}>z=0.01$ & $z=-2.54$ & $\operatorname{Pr}>z=0.01$ \\
\hline $\begin{array}{l}\text { Arellano-Bond } \\
\text { test } \operatorname{AR}(2)\end{array}$ & $z=-1.00$ & $\operatorname{Pr}>z=0.32$ & $z=-1.43$ & $\operatorname{Pr}>z=0.15$ & $z=-1.06$ & $\operatorname{Pr}>z=0.29$ \\
\hline Sargan Test & $\operatorname{chi} 2(386)=386$ & Prob $>$ chi $2=0$ & chi2(672) & Prob $>$ chi $2=0$. & $\operatorname{chi} 2(666)=796.2$ & Prob $>$ chi $2=0$ \\
\hline & & .49 & $=914.13$ & 00 & 0 & .00 \\
\hline
\end{tabular}

All the regressions reject the autocorrelation of order 2 with the Arellano-Bond test and considering the Sargan test. All the regressions reject the over identification except considering a Forward Orthogonal Deviations (FOD) transformation on a simple GMM. Table 3 shows the results considering the period 2000-2019.

Table 3: Estimations for 2000-2019

\begin{tabular}{|c|c|c|c|c|c|c|c|}
\hline Variables & $\begin{array}{l}\text { FD- } \\
\text { GMM }\end{array}$ & $\begin{array}{l}\text { SYS-FD- } \\
\text { GMM }\end{array}$ & $\begin{array}{c}\text { SYS-FD-GMM } \\
(-1)\end{array}$ & Variables & $\begin{array}{l}\text { FOD- } \\
\text { GMM }\end{array}$ & $\begin{array}{l}\text { SYS-FOD- } \\
\text { GMM }\end{array}$ & $\begin{array}{c}\text { SYS-FOD-GMM } \\
(-1)\end{array}$ \\
\hline$\Delta q_{i, t}$ & & & & $\nabla q_{i, t}$ & & & \\
\hline L1. & $0.258^{* *}$ & 0.042 & 0.076 & L1. & $0.796 * * *$ & $0.803^{* * *}$ & $0.838^{* * *}$ \\
\hline L2. & -0.121 & & & L2. & -0.120 & & $-0.120 *$ \\
\hline$\Delta \mathrm{cpi}_{i, t}$ & -0.061 & 0.099 & 0.060 & $\nabla \mathrm{cpi} i_{i, t}$ & 0.096 & 0.028 & 0.067 \\
\hline L1. & 0.194 & & 0.120 & L1. & 0.186 & & 0.233 \\
\hline L2. & 0.121 & & & L2. & -0.145 & & -0.202 \\
\hline$\Delta g d p_{i, t}$ & $0.745^{* *}$ & $0.496^{* * *}$ & $0.628^{* * *}$ & $\nabla g d p_{i, t}$ & $0.796 * * *$ & 0.056 & $0.802^{* * *}$ \\
\hline L1. & -0.182 & & -0.195 & L1. & $-0.617^{*}$ & & $-0.739 * * *$ \\
\hline L2. & $-0.436 * *$ & & & L2. & -0.325 & & -0.170 \\
\hline$\Delta i_{i, t}$ & $0.047 * *$ & 0.015 & $0.018^{*}$ & $\nabla i_{i, t}$ & $0.011 * *$ & $-0.005^{* *}$ & 0.003 \\
\hline L1. & $-0.019 *$ & & -0.008 & L1. & $-0.008^{*}$ & & $-0.005^{*}$ \\
\hline L2. & -0.000 & & & L2. & 0.003 & & 0.000 \\
\hline$\Delta g o v_{i, t}$ & 0.009 & -0.025 & -0.041 & $\nabla g o v_{i, t}$ & -0.023 & -0.000 & 0.050 \\
\hline L1. & 0.046 & & 0.030 & L1. & 0.129 & & 0.034 \\
\hline L2. & $-0.117 * *$ & & & L2. & $-0.101 *$ & & $-0.063^{*}$ \\
\hline$\Delta m_{i, t}$ & -0.012 & -0.008 & 0.011 & $\nabla m_{i, t}$ & 0.046 & $-0.083^{* *}$ & -0.024 \\
\hline L1. & -0.069 & & $-0.146^{*}$ & L1. & -0.085 & & -0.026 \\
\hline $\mathrm{L} 2$. & 0.115 & & & $\mathrm{~L} 2$. & 0.021 & & 0.18 \\
\hline$\Delta$ trade $_{i, t}$ & $-0.222^{* *}$ & $-0.208^{* * *}$ & $-0.229 * * *$ & $\nabla_{t r a d e}, t$ & -0.260 *** & -0.037 & $-0.219 * * *$ \\
\hline L1. & 0.071 & & 0.075 & L1. & $0.203^{* *}$ & & $0.191 * * *$ \\
\hline L2. & $0.197 * *$ & & & L2. & 0.068 & & 0.018 \\
\hline year2003 & $-0.108^{* *}$ & $-0.055^{* *}$ & $-0.066^{*}$ & & -3.227 & $-2.395^{*}$ & $-2.598^{*}$ \\
\hline year2006 & -0.017 & 0.013 & .003 & & -1.666 & 0.962 & -0.626 \\
\hline year2009 & 0.008 & 0.012 & 0.012 & & -1.002 & 1.146 & -0.268 \\
\hline $\mathrm{N}$ & 226 & 212 & 212 & & 203 & 231 & 217 \\
\hline
\end{tabular}


* Significance at $1 \%$ level

$* *$ Significance at $5 \%$ level

*** Significance at $10 \%$ level

The results we find in table 3 show that past values of the real exchange rate have positive and significant impacts on the current values of this variable; current values of inflation have positive impacts on most of the estimates, but not significant ones; current values of GDP have positive impacts; current values of the interest rate have positive impacts on most estimates; current values of public spending show heterogeneous and not significant effects; current values of the money supply have negative impacts; and the current values of the terms of trade have negative and significant impacts on the current values of the real exchange rate. Table 4 shows the tests applied previously, the Arellano-Bond and Sargan tests, considering the period 2000-2018.

Table 4: Testing overidentifying

\begin{tabular}{|c|c|c|c|c|c|c|}
\hline \multicolumn{7}{|c|}{ Test for period $2000-2018$} \\
\hline Test & \multicolumn{2}{|c|}{ FD-GMM } & \multicolumn{2}{|c|}{ SYS-FD-GMM } & \multicolumn{2}{|c|}{ SYS-FD-GMM(-1) } \\
\hline $\begin{array}{c}\text { Arellano-Bond } \\
\text { test } \mathrm{AR}(1)\end{array}$ & $z=-3.25$ & $\begin{array}{c}\operatorname{Pr}>z= \\
0.00\end{array}$ & $z=-3.20$ & $\begin{array}{l}\operatorname{Pr}>z \\
=0.00\end{array}$ & $z=-3.21$ & $\operatorname{Pr}>z=0.00$ \\
\hline $\begin{array}{c}\text { Arellano-Bond } \\
\text { test } \mathrm{AR}(2)\end{array}$ & $z=0.89$ & $\begin{array}{c}\operatorname{Pr}>z= \\
0.37\end{array}$ & $z=-1.99$ & $\begin{array}{l}\operatorname{Pr}>z \\
=0.05\end{array}$ & $z=-1.84$ & $\operatorname{Pr}>z=0.07$ \\
\hline Sargan Test & $\begin{array}{l}\text { chi2 }(102) \\
=183.82\end{array}$ & $\begin{array}{c}\text { Prob }>\text { chi } 2 \\
=0.00\end{array}$ & $\begin{array}{c}\operatorname{chi} 2(333)= \\
365.31\end{array}$ & $\begin{array}{c}\text { Prob }>\text { chi } 2 \\
=0.11\end{array}$ & $\begin{array}{c}\operatorname{chi} 2(329)= \\
340.24\end{array}$ & $\begin{array}{c}\text { Prob }>\text { chi } 2= \\
0.32\end{array}$ \\
\hline Test & \multicolumn{2}{|c|}{ FOD-GMM } & \multicolumn{2}{|c|}{ SYS-FOD-GMM } & \multicolumn{2}{|c|}{ SYS-FOD-GMM(-1) } \\
\hline $\begin{array}{c}\text { Arellano-Bond } \\
\text { test } \mathrm{AR}(1)\end{array}$ & . & . & -3.01 & 0.00 & -3.25 & 0.00 \\
\hline $\begin{array}{c}\text { Arellano-Bond } \\
\text { test } \mathrm{AR}(2)\end{array}$ & -2.30 & 0.02 & -2.15 & 0.03 & -1.37 & 0.17 \\
\hline Sargan Test & $\begin{array}{l}\operatorname{chi} 2(120) \\
=123.86\end{array}$ & $\begin{array}{c}\text { Prob }> \\
\text { chi2 }=0.39\end{array}$ & $\begin{array}{c}\operatorname{chi} 2(312)= \\
372.01\end{array}$ & $\begin{array}{c}\text { Prob }>\text { chi } 2 \\
=0.01\end{array}$ & $\begin{array}{c}\operatorname{chi} 2(312)= \\
287.43\end{array}$ & $\begin{array}{c}\text { Prob }>\text { chi } 2 \\
=0.56\end{array}$ \\
\hline
\end{tabular}

Considering the Arellano-Bond test shows that there is no autocorrelation of order 2 except for a simple and system GMM considering FOD transformation. Table 5 shows the results for the period 2010-2019.

Table 5: Estimations for 2010-2019

\begin{tabular}{|c|ccc|c|ccc|}
\hline Variable & $\begin{array}{c}\text { FD- } \\
\text { GMM }\end{array}$ & $\begin{array}{c}\text { SYS-FD- } \\
\text { GMM }\end{array}$ & $\begin{array}{c}\text { SYS-FD- } \\
\text { GMM (-1) }\end{array}$ & Variable & $\begin{array}{c}\text { FOD- } \\
\text { GMM }\end{array}$ & $\begin{array}{c}\text { SYS-FOD- } \\
\text { GMM }\end{array}$ & $\begin{array}{c}\text { SYS-FOD-GMM } \\
(-1)\end{array}$ \\
\hline$\Delta q_{i, t}$ & & & & $\nabla q_{i, t}$ & & & \\
L1. & 0.097 & $0.104^{*}$ & $0.289^{* *}$ & L1. & $0.917 * * *$ & $0.658^{* * *}$ & $0.980^{* * *}$ \\
L2. & 0.146 & & & L2. & -0.413 & & $-0.432^{* *}$ \\
& - & -0.093 & 0.086 & $\nabla c p i_{i, t}$ & 0.368 & 0.133 & -0.472 \\
$\Delta$ cpi $_{i, t}$ & $1.031^{* * *}$ & & & & & 0.436 \\
L1. & 0.072 & & -0.183 & L1. & -0.409 & & 0.017 \\
L2. & 0.312 & & & L2. & -0.296 & & 0.334 \\
$\Delta g d p_{i, t}$ & $-1.093^{*}$ & \multirow{2}{*}{0.076} & -0.141 & $\nabla g d p_{i, t}$ & -0.759 & $-0.322^{* *}$ & -0.401 \\
L1. & 0.413 & & $0.374^{* * *}$ & L1. & 0.503 & & -0.291 \\
L2. & $0.848^{* *}$ & & & L2. & 0.223 & & $0.055^{* *}$ \\
$\Delta i_{i, t}$ & 0.039 & $-0.035^{*}$ & -0.017 & $\nabla i_{i, t}$ & 0.077 & 0.008 & 0.027 \\
L1. & $0.082^{* *}$ & & $0.039^{*}$ & L1. & 0.005 & &
\end{tabular}


Carlos Chávez

The impact of macroeconomics factors on real exchange rate in Latin America: A dynamic panel data analysis

\begin{tabular}{|c|c|c|c|c|c|c|c|}
\hline L2. & 0.062 & & & $\mathrm{~L} 2$. & 0.021 & & 0.006 \\
\hline$\Delta g o v_{i, t}$ & 0.099 & -0.175 & -0.237 & $\nabla g o v_{i, t}$ & 0.242 & 0.096 & 0.146 \\
\hline L1. & -0.069 & & 0.004 & L1. & 0.101 & & $0.287^{*}$ \\
\hline $\mathrm{L} 2$. & 0.035 & & & $\mathrm{~L} 2$. & -0.035 & & -0.151 \\
\hline$\Delta m_{i, t}$ & -0.150 & -0.080 & -0.105 & $\nabla m_{i, t}$ & -0.166 & -0.159 & $-0.245^{*}$ \\
\hline L1. & -0.086 & & $-0.215^{*}$ & L1. & 0.026 & & 0.228 \\
\hline L2. & -0.241 & & & L2. & 0.065 & & 0.075 \\
\hline$\Delta$ trade $_{i, t}$ & $\begin{array}{c}- \\
0.540^{* * *}\end{array}$ & $-0.407 * * *$ & $-0.519 * * *$ & $\nabla_{t r a d e} i, t$ & $-0.715^{* * *}$ & $-0.132 *$ & $-0.471 *$ \\
\hline L1. & 0.022 & & $0.187^{*}$ & L1. & $0.655^{* *}$ & & $0.691 * * *$ \\
\hline $\mathrm{L} 2$. & -0.132 & & & L2. & -0.383 & & $-0.475^{* *}$ \\
\hline $\mathrm{N}$ & 72 & 90 & 86 & & 49 & 77 & 77 \\
\hline
\end{tabular}

Results in table 5 show a high ratio of past values of the real exchange rate to current values. For the current values of inflation, we find different results, but only significant and negative considering First Difference (FD) in a simple GMM estimator. The current values of the GoP have negative impacts on the current values of the real exchange rate. Considering the interest rate, we also find different results. Considering the government expenditure, different and not significant results are encountered. Considering the current values of the money supply, we find negative impacts of the current values of this variable on the real exchange rate. The current values of the terms of trade have negative impacts on the current values of the real exchange rate. Table 6 shows the Arellano-Bond and Sargan tests for the period 2010-2018.

Table 6: Testing overidentifying

\begin{tabular}{|c|c|c|c|c|c|c|}
\hline \multicolumn{7}{|c|}{ Test for period $2010-2018$} \\
\hline Test & \multicolumn{2}{|c|}{ FD-GMM } & \multicolumn{2}{|c|}{ SYS-FD-GMM } & \multicolumn{2}{|c|}{ SYS-FD-GMM(-1) } \\
\hline $\begin{array}{c}\text { Arellano-Bond } \\
\text { test } \mathrm{AR}(1)\end{array}$ & $z=-1.84$ & $\operatorname{Pr}>_{z}=0.07$ & -1.98 & $\operatorname{Pr}>z=0.05$ & -2.30 & $\operatorname{Pr}>z=0.02$ \\
\hline $\begin{array}{c}\text { Arellano-Bond } \\
\text { test } \operatorname{AR}(2)\end{array}$ & $z=-0.25$ & $\operatorname{Pr}>z=0.80$ & -1.774 & $\operatorname{Pr}>z=0.08$ & -1.06 & $\operatorname{Pr}>z=0.29$ \\
\hline Sargan Test & $\begin{array}{c}\operatorname{chi} 2(22)= \\
40.35\end{array}$ & $\begin{array}{c}\text { Prob }>\text { chi } 2 \\
\quad=0.01\end{array}$ & $\begin{array}{c}\operatorname{chi} 2(105)=114 \\
.01\end{array}$ & $\begin{array}{c}\text { Prob }>\text { chi } 2= \\
0.26\end{array}$ & $\begin{array}{c}\operatorname{chi} 2(101)=79 \\
87\end{array}$ & $\begin{array}{c}\text { Prob }>\text { chi2 }= \\
0.94\end{array}$ \\
\hline Test & \multicolumn{2}{|c|}{ FOD-GMM } & \multicolumn{2}{|c|}{ SYS-FOD-GMM } & \multicolumn{2}{|c|}{ SYS-FOD-GMM(-1) } \\
\hline $\begin{array}{l}\text { Arellano-Bond } \\
\text { test } \mathrm{AR}(1)\end{array}$ & -1.38 & 0.17 & -1.69 & 0.09 & -2.65 & 0.01 \\
\hline $\begin{array}{c}\text { Arellano-Bond } \\
\text { test } \operatorname{AR}(2)\end{array}$ & -1.79 & 0.07 & -1.62 & 0.11 & -1.77 & 0.08 \\
\hline Sargan Test & $\operatorname{chi} 2(12)=15.53$ & $\begin{array}{c}\text { Prob }> \\
\text { chi2 }=0.21\end{array}$ & $\begin{array}{c}\operatorname{chi} 2(84)=98.5 \\
9\end{array}$ & $\begin{array}{c}\text { Prob }> \\
\text { chi2 } 2=0.13\end{array}$ & $\begin{array}{c}\operatorname{chi} 2(84)=46.3 \\
7\end{array}$ & $\begin{array}{c}\text { Prob }> \\
\text { chi2 }=0.95\end{array}$ \\
\hline
\end{tabular}

The results show that there is no order-two autocorrelation for all estimates and reject the null hypothesis of over identification except for the simple GMM estimator with FD. The following figure shows the linear adjustment prediction of the real exchange rate showing that considering a FOD transformation with a GMM estimator system, there is a great predictive capacity except for Guatemala and Jamaica. 
Figure 1: Linear prediction of Exchange Rate (1980-2018)
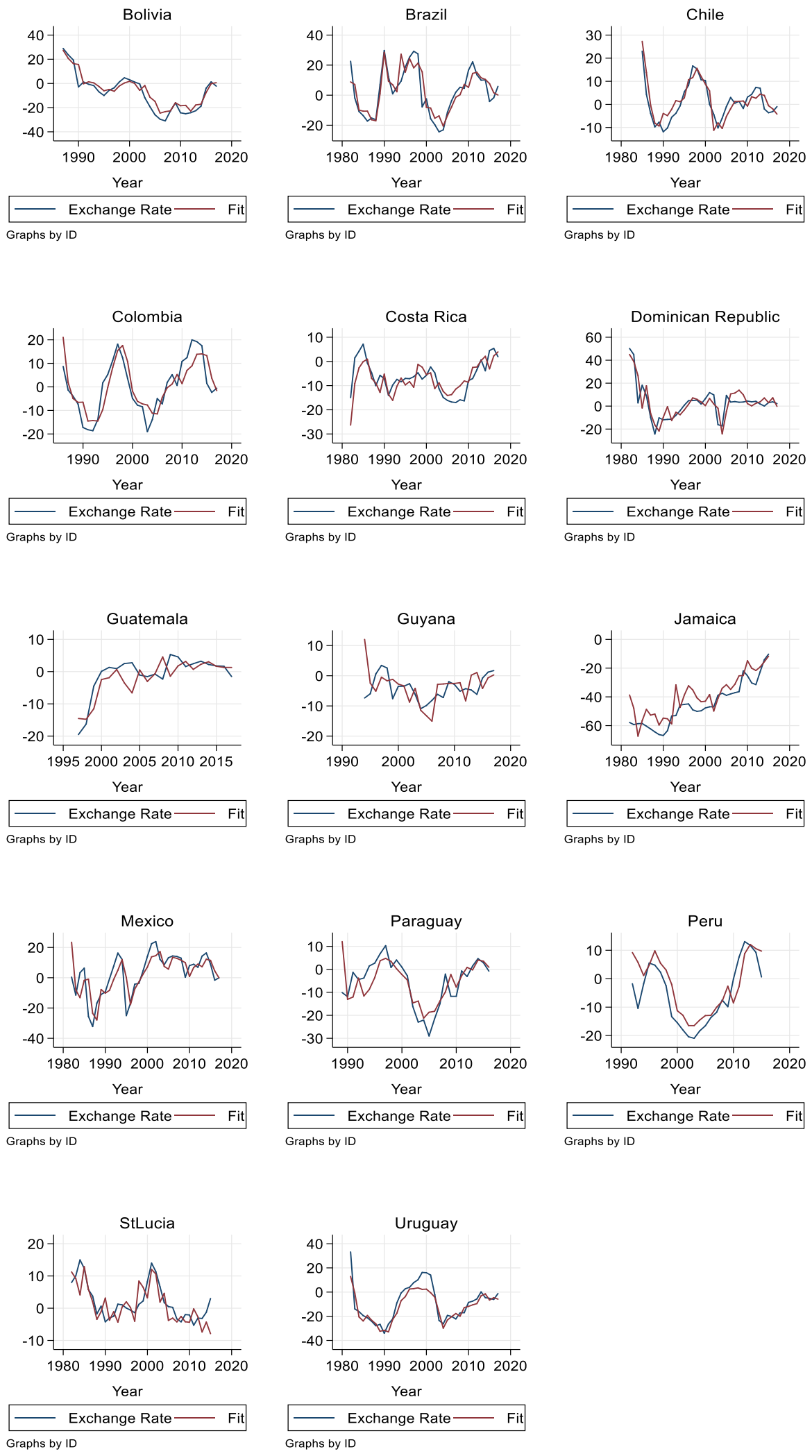

Sys Forward Orthogonal Devations GMM estimations 
The impact of macroeconomics factors on real exchange rate in Latin America: A dynamic panel data analysis

Now testing the cointegration, table 7 shows the cointegration tests between the variables included in the model and the real exchange rate using Pedroni's test. As mentioned above, this test can be interpreted considering that if $\mathrm{v}$-statistics is positive, I can reject the null hypothesis of no cointegration.

Table 7: Testing cointegration

\begin{tabular}{|c|ccc|ccc|ccc|}
\hline \multicolumn{4}{|c|}{ Pedroni Test } & \multicolumn{3}{c|}{ Pedroni Test(-1) } & \multicolumn{3}{c|}{ Pedroni Test(-2) } \\
\hline Variables & $\mathrm{v}$ & beta & t-stat & $\mathrm{v}$ & beta & $\mathrm{t}$-stat & $\mathrm{v}$ & beta & $\mathrm{t}$-stat \\
\hline cpi & 1.40 & 0.13 & 7.52 & 2.77 & 0.03 & 6.95 & 1.93 & 0.13 & 7.90 \\
gdp & 1.02 & 0.42 & 3.04 & 1.25 & 0.37 & 2.29 & 1.12 & 0.42 & 3.15 \\
gov & 0.33 & -0.50 & -0.57 & 0.44 & -0.45 & -0.63 & 0.35 & -0.50 & -0.62 \\
i & 0.41 & 0.19 & -2.76 & -0.14 & 0.19 & -1.62 & 0.16 & 0.19 & -2.54 \\
m & 0.21 & -0.14 & -1.28 & 0.13 & -0.18 & -2.04 & 0.16 & -0.14 & -1.44 \\
trade & 0.91 & -0.65 & -1.74 & 0.80 & -0.73 & -5.19 & 0.78 & -0.65 & -2.01 \\
\hline
\end{tabular}

The results show that by using lags, we can check the robustness of the test and find that cpi has a strong co-integration relationship with the real exchange rate.

\section{Conclusions and discussion}

This paper develops a dynamic data panel to predict the real exchange rate. The results show that there is a great power of adjustment with the variables included in the model, except for Guatemala and Jamaica, so it may be left for future research to include other variables that allow to improve the goodness of adjustments of the predictions. The main constrain of this paper is the small number of countries used, in this case 14, and the large number of periods used, from 1980-2019. With a larger number of countries, we could have better predictions considering smaller periods such as 2000-2019 and/or 20102019. In these estimations it must be considered the disadvantage of Arellano-Bond estimator in a system using forward orthogonal deviations for large size. Therefore, we should consider the results for a sample size $\mathrm{T}=18$. Following Judson and Owen (1999), who found that when the sample size is higher than 10 and lower than 20, this estimator or Anderson-Hsiao estimator can be chosen, hence this size is consistent with the asymptotic properties of GMM. Alvarez and Arellano (2003) found that there is consistency in GMM estimator when $\mathrm{T} / \mathrm{N}$ is higher than 0 and lower than 2 . In this case, for $\mathrm{T}=18$ and $\mathrm{N}=14$, we found that this ratio is 1.29 within the interval proposed.

Considering 1980-2019, the results show that past values of the real exchange rate have a positive and significant impact on current values of the real exchange rate. The current values of inflation, gross domestic product, the interest rate and public spending have positive impacts on the current values of the real exchange rate. While the current values of the money supply and the terms of trade have negative impacts on real exchange rate. When analyzing the period 2000-2019, the results show that past values of the real exchange rate have positive and significant impacts on the current values of this variable; current values of inflation have positive impacts on most of the estimates, but not significant ones; current values of GDP have positive impacts; current values of the interest rate have positive impacts on most estimates; current values of public spending show heterogeneous and not significant effects; current values of the money supply have negative impacts; and the current values of the terms of trade have negative and significant impacts on the current values of the real exchange rate. For the period 2010- 
2019, the results show a high ratio of past values of the real exchange rate to current values. For the current values of inflation, we find different results, but only significant and negative considering FD in a simple GMM estimator. The current values of GDP have negative impacts on the current values of the real exchange rate. Considering the interest rate, we find different results. Considering the government expenditure, we find different and not significant results. Considering the current values of the money supply, we find negative impacts of the current values of this variable on the real exchange rate. The current values of the terms of trade have negative impacts on the current values of the real exchange rate. Pedroni's test shows that there is a long-term co-integration of the real exchange rate with inflation. Finally, in the appendix, we show figure 2 that present the Kernel Density for each country by real exchange rate and its fit, and unit root test for this variables.

\section{References}

Acemoglu, D., Johnson, S., Robinson, J. A., \& Yared, P. (2008). Income and Democracy. American Economic Review, 98(3), 808-842. doi:10.1257/aer.98.3.808

Alvarez, J., \& Arellano, M. (2003). The Time Series and Cross-Section Asymptotics of Dynamic Panel Data Estimators. Econometrica, 71(4), 1121-1159. doi:10.1111/1468-0262.00441

Andrew, R. J., \& Dollery, B. E. (1990). The Microeconomics of the Pass-Through Effect: An Analysis of the Australian Motor Industry. Economic Analysis and Policy, 20(2), 141-148. doi:10.1016/s0313-5926(90)50026-0

Antoniades, A., \& Zaniboni, N. (2016). Exchange rate pass-through into retail prices. International Economic Review, 57(4), 1425-1447. doi:10.1111/iere.12203

Arellano, M., \& Bond, S. (1991). Some Tests of Specification for Panel Data: Monte Carlo Evidence and an Application to Employment Equations. The Review of Economic Studies, 58(2), 277. doi: $10.2307 / 2297968$

Arellano, M., \& Bover, O. (1995). Another look at the instrumental variable estimation of errorcomponents models. Journal of Econometrics, 68(1), 29-51. doi:10.1016/03044076(94)01642-d

Asad, I., Ahmad, N. \& Hussain, Z. (2012). Impact of real effective exchange rate on inflation in Pakistan. Asian Economic and Financial Review. 2(8), 983-990.

Athukorala, P., \& Warr, P. (2002) Vulnerability to a currency crisis: lessons from the Asian experience, World Economy, 25, 33-57.

Balassa, B. (1964). The Purchasing-Power Parity Doctrine: A Reappraisal. Journal of Political Economy, 72(6), 584-596. doi:10.1086/258965

Balázs, É., \& Amina, L.-R. (2003). Estimating the equilibrium exchange rate of the Central and Eastern European acceding countries: The challenge of euro adoption. Review of World Economics, 139(4), 683-708. doi:10.1007/bf02653109

Baltagi, B. (2005). Econometric Analysis of Panel Data. John Wiley \& Sons, Ltd. Third Edition

Beetsma, R. \& Guiliodori, M. (2011). The effects of Government Purchases Shocks: Review and Estimates for the EU. Economic Journal. 121(550). F4-F32.

Black, S. (1984). The Relationship between Exchange Rate Policy and Monetary Policy in Ten Industrial Countries. NBER Working Paper. 499-516.

Blundell, R., \& Bond, S. (1998). Initial conditions and moment restrictions in dynamic panel data models. Journal of Econometrics, 87(1), 115-143. doi:10.1016/s0304-4076(98)00009-8

Blundell-Wignall, A., Gregory, R.G., 1990. Exchange rate policy in advanced commodity-exporting countries: Australia and New Zealand. In: Argy, V., de Grauwe, P. (Eds.), Choosing an Exchange Rate Regime: The Challenge for Smaller Industrial Countries. International Monetary Fund, Washington, DC, pp. 224-284. 
The impact of macroeconomics factors on real exchange rate in Latin America: A dynamic panel data analysis

Bobba, M., \& Coviello, D. (2007). Weak instruments and weak identification, in estimating the effects of education, on democracy. Economics Letters, 96(3), 301-306. doi:10.1016/j.econlet.2007.01.018

Bouakez, H., \& Eyquem, A. (2015). Government spending, monetary policy, and the real exchange rate. Journal of International Money and Finance, 56, 178-201. doi:10.1016/j.jimonfin.2014.09.010

Branson, W. \& Love, J. (1988). The Real exchange rate, Employment, and Output in Manufacturing in the U.S and Japan. NBER. WP 1988.

Broda, C. (2004). Terms of trade and exchange rate regimes in developing countries. Journal of International Economics, 63(1), 31-58. doi:10.1016/s0022-1996(03)00043-6

Campa, J. M., \& Goldberg, L. S. (2008). Pass-Through of Exchange Rates to Consumption Prices. International Financial Issues in the Pacific Rim, 139-174. doi:10.7208/chicago/9780226387086.003.0006

Chatterjee, S. \& Musagulov, A. (2012). Fiscal Policy and the Real Exchange Rate. International Monetary Fund. WP 52.

Chen, Y. \& Rogoff, K. (2003). Commodity currencies. Journal of International Economics, 60, pp 133-169.

Choudhri, E. U., \& Schembri, L. L. (2010). Productivity, the Terms of Trade, and the Real Exchange Rate: Balassa-Samuelson Hypothesis Revisited. Review of International Economics, 18(5), 924-936. doi:10.1111/j.1467-9396.2010.00917.x

Christiano, L. J., Eichenbaum, M., \& Evans, C. (1996). The Effects of Monetary Policy Shocks: Evidence from the Flow of Funds. The Review of Economics and Statistics, 78(1), 16. doi: $10.2307 / 2109845$

Chudik, A., \& Pesaran, M. H. (2015). Common correlated effects estimation of heterogeneous dynamic panel data models with weakly exogenous regressors. Journal of Econometrics, 188(2), 393-420. doi:10.1016/j.jeconom.2015.03.007

Clarida, R. H., \& Waldman, D. (n.d.). Is Bad News about Inflation Good News for the Exchange Rate? Asset Prices and Monetary Policy, 371-396. doi:10.7208/chicago/9780226092126.003.0010

Clarida, R. \& Gertler, M.(1997). How the Bundesbank conducts monetary policy. In Christina D. Romer and David H. Romer (eds.), Reducing Inflation: Motivation and Strategy, Chicago: University of Chicago Press, 1997, pp. 363-412.

Clarida, R., Galí, J. \& Gertler, M. (1998). Monetary policy rules in practice: Some international. European Economic Review. 42(6), pp 1033-1067.

Clarida, R. (2001). The empirics of Monetary Policy Rules in Open Economics. International Journal of Finance and Economics. 6(4), pp 315-323

Cornell, B. (1982). Money Supply Announcements, Interest Rates and Foreign Exchange. Journal of International Money and Finance. 1(1982), 201-208

Corsetti, G. \& Pesenti, P. (2001). Welfare and Macroeconomic Interdependence, The Quarterly Journal of Economics, vol. 116(2), pp. 421-445.

Cottani, J. A., Cavallo, D. F., \& Khan, M. S. (1990). Real Exchange Rate Behavior and Economic Performance in LDCs. Economic Development and Cultural Change, 39(1), 61-76. doi:10.1086/451853

Coudert, V., Couharde, C., \& Mignon, V. (2015). On the impact of volatility on the real exchange rate - terms of trade nexus: Revisiting commodity currencies. Journal of International Money and Finance, 58, 110-127. doi:10.1016/j.jimonfin.2015.08.007

Cushman, D. \& Zha, T. (1997). Identifying Monetary Policy in a Small Open Economy under Flexible Exchanges Rates. Journal of Monetary Economics. 39(3) 433-48.

Rodrik, D. (2009). The Real Exchange Rate and Economic Growth. Brookings Papers on Economic Activity, 2008(2), 365-412. doi:10.1353/eca.0.0020

De Gregorio, J. \& Wolf, H. (1994). Terms of Trade, Productivity, and the Real Exchange Rate. NBER, WP 4807. 
Devereux, M. B. (1997). Real Exchange Rates and Macroeconomics: Evidence and Theory. The Canadian Journal of Economics, 30(4a), 773. doi:10.2307/136269

Di Giorgio, G., Nisticò, S. \& Traficante, G. (2015). Fiscal shocks and the Exchange Rate in a Generalized Redux Model, Economic Notes, 20, pp. 1-16.

Di Giorgio, G., Nisticò, S., \& Traficante, G. (2018). Government spending and the exchange rate. International Review of Economics \& Finance, 54, 55-73. doi:10.1016/j.iref.2017.07.030

Dooley, M. P., \& Isard, P. (1987). Country preferences, currency values and policy issues. Journal of Policy Modeling, 9(1), 65-81. doi:10.1016/0161-8938(87)90004-4

Dormbusch, R. \& Fischer, S. (1980). Exchange Rates and The Current Account. American Economic Review. 70(5) 960-971

Dornbusch, R. \& Jaffee, D. (1978). Purchasing power parity and exchange rate problems introduction. Journal of International Economics. 8(2), pp 157-161.

Dornbusch, R. (1980). Exchange rate risk and the macroeconomics of exchange rate determination. NBER. WP 493.

Dornbusch, R. (1987). Exchange Rates and Prices. The American Economic Review, 77(1), 93-106.

Edwards, S. (1987). Real Exchange Rates, Devaluation and Adjustment. Cambridge, Mass.: MIT Press.

Edwards, S. (1999) On crisis prevention: lessons from Mexico and East Asia, National Bureau of Economic Research Working Paper 7233, National Bureau of Economics Research (NBER), Cambridge

Edwards, S. (2000) Exchange rates in emerging economies: what do we know? What do we need to know? in Economic Policy Reform: The Second Stage (Ed.) A. Krueger, University of Chicago Press, London, pp. 453-510.

Eichenbaum, M., \& Evans, C. L. (1995). Some Empirical Evidence on the Effects of Shocks to Monetary Policy on Exchange Rates. The Quarterly Journal of Economics, 110(4), 975-1009. doi: $10.2307 / 2946646$

Eichenbaum, M., \& Evans, C. L. (1995). Some Empirical Evidence on the Effects of Shocks to Monetary Policy on Exchange Rates. The Quarterly Journal of Economics, 110(4), 975-1009. doi: $10.2307 / 2946646$

Enders, Z., Müller, G. J., \& Scholl, A. (2011). How do fiscal and technology shocks affect real exchange rates? Journal of International Economics, 83(1), 53-69. doi:10.1016/j.jinteco.2010.08.005

Frenkel, J. A. (1976). A Monetary Approach to the Exchange Rate: Doctrinal Aspects and Empirical Evidence. The Scandinavian Journal of Economics, 78(2), 200. doi:10.2307/3439924

Gagnon, J. \& Ihrig, J. (2001). Monetary policy and exchange rate pass-through. International Finance Discussion Papers 704, Board of Governors of the Federal Reserve System

Ganelli, G. (2005). Home Bias in Government Spending and Quasi Neutrality of Fiscal Shocks, Macroeconomic Dynamics, 9, 288-294.

Ghura, D., \& Grennes, T. J. (1993). The real exchange rate and macroeconomic performance in Sub-Saharan Africa. Journal of Development Economics, 42(1), 155-174. doi:10.1016/03043878(93)90077-z

Goldberg, P. \& Knetter, M. (1996). Good prices and Exchange rates: What have we learned? NBER. WP 5862.

Goldstein, M. (1998). The Asian Financial Crisis: Causes, Cures, and Systemic Implications, Institute for International Economics, Washington DC.

Grilli, V. \& Roubini, N. (1995). Liquidity and Exchange Rates: Puzzling Evidence From the G-7 Countries. New York University: Salomon Brothers. Working Paper.

Gruen, D. \& Wilkinson, J. (1994). Australia's real exchange rate-is it explained by the terms of trade or by real interest differentials? Economic Record 70 (209), 204-219.

Guzman, M., Ocampo, J. A., \& Stiglitz, J. E. (2018). Real exchange rate policies for economic development. World Development, 110, 51-62. doi:10.1016/j.worlddev.2018.05.017 
Carlos Chávez

The impact of macroeconomics factors on real exchange rate in Latin America: A dynamic panel data analysis

Habib, M. M., Mileva, E., \& Stracca, L. (2017). The real exchange rate and economic growth: Revisiting the case using external instruments. Journal of International Money and Finance, 73, 386-398. doi:10.1016/j.jimonfin.2017.02.014

Hayakawa, K. (2008). First Difference or Forward Orthogonal Deviation - Which Transformation Should be Used in Dynamic Panel Data Models?: A simulation study. Economics Bulletin. 29(3), 1-7.

Heid, B., Langer, J., \& Larch, M. (2012). Income and democracy: Evidence from system GMM estimates. Economics Letters, 116(2), 166-169. doi:10.1016/j.econlet.2012.02.009

Hüfner, F. P., \& Schröder, M. (2002). Exchange Rate Pass-through to Consumer Prices: A European Perspective. SSRN Electronic Journal. doi:10.2139/ssrn.304939

Hujer, R., Rodrigues, P. \& Zeiss, C. (2005), Serial Correlation in Dynamic Panel Data Models with Weakly Exogenous Regressors and Fixed Effects. Goethe-University, Frankfurt, Germany.

Husted, S., \& Kitchen, J. (1985). Some Evidence on the International Transmission of U. S. Money Supply Announcement Effects. Journal of Money, Credit and Banking, 17(4), 456. doi: $10.2307 / 1992441$

Isard, P. (2007). Equilibrium Exchange Rates: Assessment Methodologies. IMF Working Papers, 07(296), 1. doi:10.5089/9781451868593.001

Isard, P., Ito, T. \& Symansky, S. (1997). Economic growth and Real exchange rate: An overview of the Balassa-Samuelson hypothesis in Asia. NBER. WP 5979.

Jongwanich, J. (2008). Real exchange rate overvaluation and currency crisis: evidence from Thailand. Applied Economics, 40(3), 373-382. doi:10.1080/00036840600570961

Judson, R. A., \& Owen, A. L. (1999). Estimating dynamic panel data models: a guide for macroeconomists. Economics Letters, 65(1), 9-15. doi:10.1016/s0165-1765(99)00130-5

Kim, K. H. (1998), US inflation and the dollar exchange rate: A vector error correction model, Applied Economics 30 (5), 613-619.

Kim, S. \& Roubini, N. (2008). Twin Deficit or Twin Divergence? Fiscal Policy, Current Account, and Real Exchange Rate in the US, Journal of International Economics vol. 4, 362-383.

Kohlscheen, E. (2014). The impact of monetary policy on the exchange rate: A high frequency exchange rate puzzle in emerging economies. Journal of International Money and Finance, 44, 69-96. doi:10.1016/j.jimonfin.2014.01.005

Koya, S.N. \& Orden, D. (1994). Terms of trade and the exchange rates of New Zealand and Australia. Applied Economics 26 (5), 451-457.

Kuijs, L. (1998). Determinants of Inflation, Exchange Rate, and Output in Nigeria. IMF Working Papers, 98(160), 1. doi:10.5089/9781451981735.001

Macdonald, R. \& Taylor, M. (1991). The Monetary Approach to the Exchange Rate: Long-run relationship and Coefficient Restrictions. Economics Letters. 37(1991). 179-185.

Macdonald, R., \& Taylor, M. (1993). The Monetary Approach to the Exchange Rate: Rational Expectations, Long-Run Equilibrium, and Forecasting. Staff Papers (International Monetary Fund), 40(1), 89-107. doi:10.2307/3867378

Maitra, B. (2010). Money Supply and Exchange Rate Variations in Sri Lanka in the Independent Float Regime: A Time Domain Study. South Asia Economic Journal. 11(1), pp. 111-129.

Mann, C.L. (1986), "Prices, Profit Margins and Exchange Rates", Federal Reserve Bulletin, Vol.72 No.6, 366-79.

McCandless, G. \& Weber, W. (1995). Some monetary facts. Federal Reserve Bank of Minneapolis

McKinnon, I. (1998) Exchange rate coordination for surmounting the East Asian crisis, Asian Economic Journal, 12, 317-29.

Mcnown, R. \& Wallace, M. (1994). Cointegration Tests of the Monetary Exchange Rate Model for three High Inflation Economics. Journal of Money, Credit and Banking. 26(3), pp. 396-411.

Mendoza, E. (1995). The Term of Trade, the Real Exchange Rate, and Economic Fluctuations. International Economic Review, 36(1), pp 101-137.

Menon, J. (1995). Exchange rate pass-through. Journal of Economic Surveys, 9(2), 197-231. doi:10.1111/j.1467-6419.1995.tb00114.x 
Messe, R. \& Rogoff, K. (1988). Was it Real? The exchange rate-interest differential relation over the modern floating-rate period. Journal of Finance, 43(4), 933-948.

Mesquita, M., Pierola, M. D., \& Sánchez-Navarro, D. (2017). Exchange rate devaluation and import substitution in Latin America and the Caribbean. IDB Technical Note 1275, Inter-American Development Bank.

Miyamoto, W., Nguyen, T. L., \& Sheremirov, V. (2019). The effects of government spending on real exchange rates: Evidence from military spending panel data. Journal of International Economics, 116, 144-157. doi:10.1016/j.jinteco.2018.11.009

Monacelli, T. \& Perotti, R. (2010). Fiscal Policy, the Real Exchange Rate and Traded Goods., The Economic Journal vol. 120, pp. 437

Moral-Benito, E., Allison, P., \& Williams, R. (2018). Dynamic panel data modelling using maximum likelihood: an alternative to Arellano-Bond. Applied Economics, 51(20), 2221-2232. doi:10.1080/00036846.2018.1540854

Neal, T. (2014). Panel Cointegration Analysis with Xtpedroni. The Stata Journal: Promoting Communications on Statistics and Stata, 14(3), 684-692. doi:10.1177/1536867x1401400312

Neary, J. (1988). Determinants of the Equilibrium Real Exchange Rate. American Economic Review. 87(1), pp 210-215

Nikolaou, K. (2008). The behavior of the real exchange rate: Evidence from regression quantiles. Journal of Banking \& Finance, 32(5), 664-679. doi:10.1016/j.jbankfin.2007.05.002

Obstfeld, M. \& Rogoff, K. (1995). Exchange Rate Dynamics Redux. Journal of Political Economy, 103, 624-60

Pedroni, P. (1999). Critical Values for Cointegration Tests in Heterogeneous Panels with Multiple Regressors. Oxford Bulletin of Economics and Statistics, 61(s1), 653-670. doi:10.1111/14680084.61.s1.14

Pedroni, P. (2004). Panel Cointegration: Asymptotic and finite sample properties of pooled time series tests with an application to the PPP hypothesis. Econometric Theory, 20(03). doi:10.1017/s0266466604203073

Penati, A. (1987). Government spending and the real exchange rate. Journal of International Economics, 22(3-4), 237-256. doi:10.1016/s0022-1996(87)80022-3

Radelet, S. and Sachs, J. (1998) The East Asian financial crisis: diagnosis, remedies, prospects, Brookings Papers on Economic Activity, 2, 1-89.

Ravn, M. O., Schmitt-Grohé, S., \& Uribe, M. (2012). Consumption, government spending, and the real exchange rate. Journal of Monetary Economics, 59(3), 215-234. doi:10.1016/j.jmoneco.2012.02.001

Razin, O., \& Collins, S. M. (n.d.). Real-Exchange-Rate Misalignments and Growth. The Economics of Globalization, 59-82. doi:10.1017/cbo9780511619946.005

Razzak, W. \& Grennes, T. (1997). The Long-Run Exchange Rate: Specification and Estimation. Working Paper G98/5, Reserve Bank of New Zealand.

Razzaque, M. A., Bidisha, S. H., \& Khondker, B. H. (2017). Exchange Rate and Economic Growth. Journal of South Asian Development, 12(1), 42-64. doi:10.1177/0973174117702712

Rogoff, K. (2003). Evolution and Performance of Exchange Rate Regimes. International Monetary Fund. WP 243.

Roodman, D. (2009). How to do Xtabond2: An Introduction to Difference and System GMM in Stata. The Stata Journal: Promoting Communications on Statistics and Stata, 9(1), 86-136. doi:10.1177/1536867x0900900106

Samuelson, P. A. (1994). Facets of Balassa-Samuelson Thirty Years Later. Review of International Economics, 2(3), 201-226. doi:10.1111/j.1467-9396.1994.tb00041.x

Stein, J. L., Allen, P. R. and associates (1995) Fundamental Determinants of Exchange Rates, Clarendon Press, Oxford.

Taylor, J. B. (2001). The Role of the Exchange Rate in Monetary-Policy Rules. American Economic Review, 91(2), 263-267. doi:10.1257/aer.91.2.263 
The impact of macroeconomics factors on real exchange rate in Latin America: A dynamic panel data analysis

Taylor, M. \& Peel, D. (2000). Nonlinear Adjustment, Long-Run Equilibrium and Exchange Rate Fundamentals. Journal of International Money and Finance. 19(1), pp, 33-53.

Walsh, C. (2010). Monetary theory and policy. The MIT Press. Third edition.

Wasserfallen, W. \& Kursteiner, G. (1994). Interest rates and Exchange Rates under Money Supply Targets. Journal of Monetary Economics. 33(1994) 201-230.

Williamson, J. (1983) The Exchange Rate System, Institute for International Economics, Washington, DC.

Williamson, J. (1994) Estimating Equilibrium Exchange Rates, Institute for International Macroeconomics, Washington, DC.

Windmeijer, F. (2005). A finite sample correction for the variance of linear efficient two-step GMM estimators. Journal of Econometrics, 126(1), 25-51. doi:10.1016/j.jeconom.2004.02.005

Woodford, M. (2004). Inflation Targeting and Optimal Monetary Policy. Review, 86(4). doi:10.20955/r.86.15-42

World Bank (2018). World Development Indicators, https://databank.worldbank.org/metadataglossary/world-development-indicators/series

Zettelmeer, J. (2004). The impact of Monetary Policy on the Exchange Rate: Evidence from three small open economies. Journal of Monetary Economics. 51(3), 635-652. 


\section{Appendix}

The following tables shows the unit root test for each country using Augmented Dickey-Fuller test whose null hypothesis is presence of unit root, and unit root test for panel data using Im-PesaranShin test whose null hypothesis is all panel data contain unit root but in case of reject the null hypothesis, cannot accept not presence of unit root but some panels are stationary.

Table 8. Unit root test for $1980-2018$ period

\begin{tabular}{|c|c|c|c|c|c|c|c|c|}
\hline Countries & $\begin{array}{c}\mathrm{ADF} \\
\text { Statistics }\end{array}$ & $\begin{array}{c}\text { Gross } \\
\text { Domesti } \\
\text { c } \\
\text { Product }\end{array}$ & $\begin{array}{c}\text { Consumer } \\
\text { Price } \\
\text { Index }\end{array}$ & $\begin{array}{c}\text { Deposit } \\
\text { Interest } \\
\text { Rate }\end{array}$ & $\begin{array}{c}\text { Real } \\
\text { Exchang } \\
\text { e Rate }\end{array}$ & $\begin{array}{l}\text { Government } \\
\text { Spend }\end{array}$ & $\begin{array}{l}\text { Broad } \\
\text { Money }\end{array}$ & $\begin{array}{l}\text { Trade } \\
\text { ( } \% \text { of } \\
\text { GDP) }\end{array}$ \\
\hline \multirow{2}{*}{ Bolivia } & $\begin{array}{c}\text { ADF } \\
\text { Statistics }\end{array}$ & 8.844 & 1.678 & -2.556 & -1.110 & -1.239 & -1.034 & -1.407 \\
\hline & $\mathrm{P}$-value & 1.000 & 0.998 & 0.102 & 0.711 & 0.657 & 0.741 & 0.579 \\
\hline \multirow{2}{*}{ Brazil } & $\begin{array}{c}\text { ADF } \\
\text { Statistics }\end{array}$ & 0.149 & 2.915 & $-3.470 * * *$ & -2.372 & -1.925 & -2.344 & -1.158 \\
\hline & $\mathrm{P}$-value & 0.969 & 1.000 & 0.009 & 0.150 & 0.320 & 0.158 & 0.692 \\
\hline \multirow[t]{2}{*}{ Chile } & $\begin{array}{c}\text { ADF } \\
\text { Statistics }\end{array}$ & 1.212 & -1.252 & -2.469 & $-3.396 * *$ & -0.481 & -1.137 & -1.764 \\
\hline & $\mathrm{P}$-value & 0.996 & 0.651 & 0.123 & 0.011 & 0.896 & 0.700 & 0.399 \\
\hline \multirow{2}{*}{ Colombia } & $\begin{array}{c}\text { ADF } \\
\text { Statistics }\end{array}$ & 2.467 & 1.807 & -1.030 & -1.828 & -1.974 & 0.180 & -2.717 \\
\hline & $\mathrm{P}$-value & 0.999 & 0.998 & 0.742 & 0.367 & 0.298 & 0.971 & 0.071 \\
\hline \multirow{2}{*}{ Costa Rica } & $\begin{array}{c}\text { ADF } \\
\text { Statistics }\end{array}$ & 3.918 & 2.601 & -1.454 & -1.755 & -1.641 & -1.415 & -1.617 \\
\hline & P-value & 1.000 & 0.999 & 0.556 & 0.403 & 0.462 & 0.575 & 0.474 \\
\hline \multirow{2}{*}{$\begin{array}{l}\text { Dominican } \\
\text { Republic }\end{array}$} & $\begin{array}{c}\text { ADF } \\
\text { Statistics }\end{array}$ & -2.135 & $-2.967 * *$ & 0.296 & $-2.925^{* *}$ & -0.436 & -2.201 & -2.766 \\
\hline & $\mathrm{P}$-value & 0.231 & 0.038 & 0.977 & 0.043 & 0.904 & 0.206 & 0.063 \\
\hline \multirow[t]{2}{*}{ Guatemala } & $\begin{array}{c}\text { ADF } \\
\text { Statistics }\end{array}$ & 2.129 & 1.028 & -1.622 & $-4.376^{* * *}$ & $-2.839 *$ & -1.950 & -1.695 \\
\hline & P-value & 0.999 & 0.995 & 0.472 & 0.000 & 0.053 & 0.309 & 0.434 \\
\hline \multirow[t]{2}{*}{ Guyana } & $\begin{array}{c}\text { ADF } \\
\text { Statistics }\end{array}$ & 1.814 & -1.281 & -1.737 & -1.625 & -1.619 & -1.671 & -0.943 \\
\hline & $\mathrm{P}$-value & 0.998 & 0.638 & 0.412 & 0.470 & 0.473 & 0.446 & 0.774 \\
\hline \multirow{2}{*}{ Jamaica } & $\begin{array}{c}\text { ADF } \\
\text { Statistics }\end{array}$ & -1.694 & 5.530 & -1.323 & 2.051 & -2.159 & -2.957 & -3.965 \\
\hline & P-value & 0.434 & 1.000 & 0.619 & 0.999 & 0.221 & 0.039 & 0.002 \\
\hline \multirow[t]{2}{*}{ Mexico } & $\begin{array}{c}\text { ADF } \\
\text { Statistics }\end{array}$ & 1.035 & 3.019 & -1.335 & -2.915 & -0.855 & -1.585 & -0.279 \\
\hline & P-value & 0.995 & 1.000 & 0.613 & 0.044 & 0.802 & 0.491 & 0.928 \\
\hline \multirow[t]{2}{*}{ Paraguay } & $\begin{array}{c}\text { ADF } \\
\text { Statistics }\end{array}$ & 2.729 & 1.909 & -1.248 & -1.482 & -1.522 & -1.480 & -1.340 \\
\hline & P-value & 0.999 & 0.999 & 0.653 & 0.543 & 0.523 & 0.544 & 0.611 \\
\hline \multirow[t]{2}{*}{ Peru } & $\begin{array}{c}\text { ADF } \\
\text { Statistics }\end{array}$ & 3.005 & $-6.536 * * *$ & $-239.217^{* * *}$ & -1.929 & -1.460 & -0.304 & -1.082 \\
\hline & P-value & 1.000 & 0.000 & 0.000 & 0.319 & 0.553 & 0.925 & 0.722 \\
\hline \multirow[t]{2}{*}{ St. Lucia } & $\begin{array}{c}\mathrm{ADF} \\
\text { Statistics }\end{array}$ & -1.713 & -1.269 & -0.918 & -2.016 & -1.622 & -1.639 & -2.500 \\
\hline & P-value & 0.424 & 0.643 & 0.782 & 0.280 & 0.472 & 0.463 & 0.115 \\
\hline \multirow{2}{*}{ Uruguay } & $\begin{array}{c}\text { ADF } \\
\text { Statistics }\end{array}$ & 1.865 & 11.154 & -1.344 & -1.662 & -1.603 & $-2.666^{*}$ & -1.888 \\
\hline & P-value & 0.998 & 1.000 & 0.609 & 0.451 & 0.482 & 0.080 & 0.338 \\
\hline
\end{tabular}

* Significance at $1 \%$ level

** Significance at $5 \%$ level

*** Significance at $10 \%$ level 
Carlos Chávez

The impact of macroeconomics factors on real exchange rate in Latin America: A dynamic panel data analysis

Table 9: First difference

\begin{tabular}{|c|c|c|c|c|c|c|c|c|}
\hline Countries & $\begin{array}{c}\text { ADF } \\
\text { Statistics }\end{array}$ & $\begin{array}{c}\text { Gross } \\
\text { Domestic } \\
\text { Product }\end{array}$ & $\begin{array}{c}\text { Consumer } \\
\text { Price } \\
\text { Index }\end{array}$ & $\begin{array}{c}\text { Deposit } \\
\text { Interest } \\
\text { Rate }\end{array}$ & $\begin{array}{c}\text { Real } \\
\text { Exchang } \\
\text { e Rate }\end{array}$ & $\begin{array}{l}\text { Government } \\
\text { Spend }\end{array}$ & $\begin{array}{l}\text { Broad } \\
\text { Money }\end{array}$ & $\begin{array}{l}\text { Trade }(\% \\
\text { of GDP) }\end{array}$ \\
\hline \multirow{2}{*}{ Bolivia } & ADF Statistics & $-3.677 * * *$ & $-2.585^{*}$ & $-5.565^{* * *}$ & $-3.712 * * *$ & $-5.105^{* * *}$ & $-4.92 * * *$ & $-4.659 * * *$ \\
\hline & $\mathrm{P}$-value & 0.004 & 0.096 & 0.000 & 0.004 & 0.000 & 0.000 & 0.000 \\
\hline \multirow{2}{*}{ Brazil } & ADF Statistics & $-4.685^{* * *}$ & -1.723 & $-5.714^{* * *}$ & $-5.244 * * *$ & $-6.411 * * *$ & $-5.88 * * *$ & $-5.717 * * *$ \\
\hline & P-value & 0.000 & 0.419 & 0.000 & 0.000 & 0.000 & 0.000 & 0.000 \\
\hline \multirow{2}{*}{ Chile } & ADF Statistics & $-3.747 * * *$ & -1.794 & $-6.099 * * *$ & $-4.612^{* * *}$ & $-4.085^{* * *}$ & $-5.31 * * *$ & $-4.759 * * *$ \\
\hline & P-value & 0.003 & 0.384 & 0.000 & 0.000 & 0.001 & 0.000 & 0.000 \\
\hline \multirow{2}{*}{ Colombia } & ADF Statistics & $-6.177 * * *$ & $-3.062^{* *}$ & $-6.260 * * *$ & $-6.476 * * *$ & $-4.738 * * *$ & $-6.12 * * *$ & $-5.313^{* * *}$ \\
\hline & P-value & 0.000 & 0.029 & 0.000 & 0.000 & 0.000 & 0.000 & 0.000 \\
\hline \multirow{2}{*}{ Costa Rica } & ADF Statistics & $-3.512^{* * *}$ & -0.829 & $-5.085^{* * *}$ & $-4.141 * * *$ & $-5.437 * * *$ & $-5.61 * * *$ & $-7.117 * * *$ \\
\hline & P-value & 0.008 & 0.811 & 0.000 & 0.001 & 0.000 & 0.000 & 0.000 \\
\hline \multirow{2}{*}{$\begin{array}{l}\text { Dominican } \\
\text { Republic }\end{array}$} & ADF Statistics & $-5.712^{* * *}$ & $-5.888^{* * *}$ & $-5.913 * * *$ & $-6.480^{* * *}$ & $-5.819 * * *$ & $-7.81 * * *$ & $-8.237 * * *$ \\
\hline & P-value & 0.000 & 0.000 & 0.000 & 0.000 & 0.000 & 0.000 & 0.000 \\
\hline \multirow{2}{*}{ Guatemala } & ADF Statistics & $-3.454 * * *$ & $-3.240^{* *}$ & $-2.619^{*}$ & $-3.115^{* *}$ & $-3.396^{* *}$ & $-4.61 * * *$ & $-3.855^{* * *}$ \\
\hline & P-value & 0.009 & 0.018 & 0.089 & 0.025 & 0.011 & 0.000 & 0.002 \\
\hline \multirow{2}{*}{ Guyana } & ADF Statistics & $-3.589 * * *$ & $-2.771 *$ & $-3.143^{* *}$ & $-4.583^{* * *}$ & $-4.593^{* * *}$ & $-3.76^{* * *}$ & $-4.766^{* * *}$ \\
\hline & P-value & 0.006 & 0.063 & 0.024 & 0.000 & 0.000 & 0.003 & 0.000 \\
\hline \multirow{2}{*}{ Jamaica } & ADF Statistics & $-3.705^{* * *}$ & $-2.826^{* *}$ & $-6.703^{* * *}$ & $-3.896^{* * *}$ & $-4.166^{* * *}$ & $-6.68 * * *$ & $-8.071 * * *$ \\
\hline & P-value & 0.004 & 0.055 & 0.000 & 0.002 & 0.001 & 0.000 & 0.000 \\
\hline \multirow[t]{2}{*}{ Mexico } & ADF Statistics & $-6.743 * * *$ & -1.754 & $-4.466^{* * *}$ & $-5.871 * * *$ & $-5.939 * * *$ & $\begin{array}{c}- \\
7.027^{* *} \\
*\end{array}$ & $-5.397 * * *$ \\
\hline & P-value & 0.000 & 0.403 & 0.000 & 0.000 & 0.000 & 0.000 & 0.000 \\
\hline \multirow{2}{*}{ Paraguay } & ADF Statistics & $-4.408^{* * *}$ & $-4.367 * * *$ & $-5.106 * * *$ & $-4.973 * * *$ & $-4.406 * * *$ & $-3.75 * * *$ & $-5.427 * * *$ \\
\hline & P-value & 0.000 & 0.000 & 0.000 & 0.000 & 0.000 & 0.004 & 0.000 \\
\hline \multirow{2}{*}{ Peru } & ADF Statistics & -3.933 & -25.471 & -5.876 & -4.832 & -4.240 & -7.505 & -4.715 \\
\hline & P-value & 0.002 & 0.000 & 0.000 & 0.000 & 0.001 & 0.000 & 0.000 \\
\hline \multirow{2}{*}{ St. Lucia } & ADF Statistics & $-4.310^{* * *}$ & $-6.582^{* * *}$ & $-7.170^{* * *}$ & $-5.246 * * *$ & $-5.156^{* * *}$ & $-5.69 * * *$ & $-6.507 * * *$ \\
\hline & P-value & 0.000 & 0.000 & 0.000 & 0.000 & 0.000 & 0.000 & 0.000 \\
\hline \multirow{2}{*}{ Uruguay } & ADF Statistics & $-3.212^{* * *}$ & $-0.936 * * *$ & $-4.322^{* * *}$ & $-5.057 * * *$ & $-6.044^{* * *}$ & $-6.08^{* * *}$ & $-5.960 * * *$ \\
\hline & P-value & 0.019 & 0.776 & 0.000 & 0.000 & 0.000 & 0.000 & 0.000 \\
\hline
\end{tabular}

* Significance at $1 \%$ level

** Significance at $5 \%$ level

*** Significance at $10 \%$ level 
Latin American Journal of Trade Policy 8 (2020) - Universidad de Chile

Table 10: Forward Orthogonal Deviations

\begin{tabular}{|c|c|c|c|c|c|c|c|c|}
\hline Countries & $\begin{array}{c}\mathrm{ADF} \\
\text { Statistics }\end{array}$ & $\begin{array}{c}\text { Gross } \\
\text { Domestic } \\
\text { Product }\end{array}$ & $\begin{array}{l}\text { Consumer } \\
\text { Price Index }\end{array}$ & $\begin{array}{c}\text { Deposit } \\
\text { Interest Rate }\end{array}$ & $\begin{array}{c}\text { Real } \\
\text { Exchange } \\
\text { Rate }\end{array}$ & $\begin{array}{l}\text { Government } \\
\text { Spend }\end{array}$ & $\begin{array}{l}\text { Broad } \\
\text { Money }\end{array}$ & $\begin{array}{l}\text { Trade } \\
(\% \text { of } \\
\text { GDP) } \\
\end{array}$ \\
\hline \multirow{2}{*}{ Bolivia } & $\begin{array}{c}\text { ADF } \\
\text { Statistics }\end{array}$ & 5.200 & 1.196 & -1.810 & $-2.599 *$ & -1.950 & -1.164 & -1.260 \\
\hline & $\mathrm{P}$-value & 1.000 & 0.996 & 0.376 & 0.093 & 0.309 & 0.689 & 0.647 \\
\hline \multirow{2}{*}{ Brazil } & $\begin{array}{c}\text { ADF } \\
\text { Statistics }\end{array}$ & 0.358 & 1.289 & $-3.613 * * *$ & -2.422 & -1.764 & $\begin{array}{c}- \\
3.432^{* *}\end{array}$ & -1.930 \\
\hline & P-value & 0.980 & 0.997 & 0.006 & 0.136 & 0.398 & 0.010 & 0.318 \\
\hline \multirow{2}{*}{ Chile } & $\begin{array}{c}\text { ADF } \\
\text { Statistics }\end{array}$ & 0.693 & -1.266 & $-2.773 *$ & $-3.251 * *$ & -2.372 & -1.206 & -1.681 \\
\hline & P-value & 0.990 & 0.644 & 0.062 & 0.017 & 0.150 & 0.671 & 0.441 \\
\hline \multirow[t]{2}{*}{ Colombia } & $\begin{array}{c}\text { ADF } \\
\text { Statistics }\end{array}$ & 1.589 & 1.373 & -1.196 & -1.826 & -1.900 & -1.031 & $-2.858^{*}$ \\
\hline & P-value & 0.998 & 0.997 & 0.675 & 0.368 & 0.332 & 0.742 & 0.050 \\
\hline \multirow{2}{*}{ Costa Rica } & $\begin{array}{c}\text { ADF } \\
\text { Statistics }\end{array}$ & 2.585 & 2.710 & -2.313 & -2.209 & -2.036 & -1.626 & -1.692 \\
\hline & P-value & 0.999 & 0.999 & 0.168 & 0.203 & 0.271 & 0.470 & 0.435 \\
\hline \multirow{2}{*}{$\begin{array}{l}\text { Dominican } \\
\text { Republic }\end{array}$} & $\begin{array}{c}\text { ADF } \\
\text { Statistics }\end{array}$ & -1.398 & -1.966 & -2.162 & $-2.860 *$ & -1.391 & -2.530 & -2.837 \\
\hline & P-value & 0.583 & 0.302 & 0.221 & 0.050 & 0.587 & 0.108 & 0.053 \\
\hline \multirow{2}{*}{ Guatemala } & $\begin{array}{c}\text { ADF } \\
\text { Statistics }\end{array}$ & 1.172 & 0.770 & -1.672 & $-4.232 * * *$ & -2.491 & -1.717 & -2.473 \\
\hline & $\mathrm{P}$-value & 0.996 & 0.991 & 0.446 & 0.001 & 0.118 & 0.423 & 0.122 \\
\hline \multirow[t]{2}{*}{ Guyana } & $\begin{array}{c}\text { ADF } \\
\text { Statistics }\end{array}$ & 0.455 & -0.252 & -1.368 & -2.228 & -1.726 & -1.910 & -1.417 \\
\hline & $\mathrm{P}$-value & 0.983 & 0.932 & 0.597 & 0.196 & 0.418 & 0.327 & 0.574 \\
\hline \multirow{2}{*}{ Jamaica } & $\begin{array}{c}\text { ADF } \\
\text { Statistics }\end{array}$ & -1.378 & 3.234 & -2.216 & 1.265 & -2.099 & -2.939 & $-4.694 * * *$ \\
\hline & P-value & 0.593 & 1.000 & 0.200 & 0.996 & 0.245 & 0.041 & 0.000 \\
\hline \multirow[t]{2}{*}{ Mexico } & $\begin{array}{c}\text { ADF } \\
\text { Statistics }\end{array}$ & 0.133 & 1.743 & -1.716 & $-3.032 * *$ & -1.555 & -2.944 & -1.587 \\
\hline & P-value & 0.968 & 0.998 & 0.423 & 0.032 & 0.506 & 0.040 & 0.490 \\
\hline \multirow{2}{*}{ Paraguay } & $\begin{array}{c}\text { ADF } \\
\text { Statistics }\end{array}$ & 0.772 & 1.450 & -1.460 & -1.741 & -1.798 & -0.432 & -1.906 \\
\hline & $\mathrm{P}$-value & 0.991 & 0.997 & 0.553 & 0.410 & 0.381 & 0.905 & 0.329 \\
\hline \multirow[t]{2}{*}{ Peru } & $\begin{array}{c}\text { ADF } \\
\text { Statistics }\end{array}$ & 1.830 & $-8.389 * * *$ & $-251.445^{* * *}$ & -1.826 & -1.881 & -0.942 & -1.050 \\
\hline & P-value & 0.998 & 0.000 & 0.000 & 0.368 & 0.341 & 0.774 & 0.734 \\
\hline \multirow{2}{*}{ St. Lucia } & $\begin{array}{c}\text { ADF } \\
\text { Statistics }\end{array}$ & -1.381 & -0.426 & -1.784 & -2.251 & -1.727 & -1.195 & -3.676 \\
\hline & P-value & 0.592 & 0.906 & 0.389 & 0.188 & 0.417 & 0.676 & 0.004 \\
\hline \multirow{2}{*}{ Uruguay } & $\begin{array}{c}\text { ADF } \\
\text { Statistics }\end{array}$ & 0.448 & 4.483 & -1.788 & -2.174 & -1.922 & $-2.632 *$ & -1.846 \\
\hline & P-value & 0.983 & 1.000 & 0.386 & 0.216 & 0.322 & 0.087 & 0.358 \\
\hline
\end{tabular}

$*$ Significance at $1 \%$ level

** Significance at 5\% level

*** Significance at $10 \%$ level 
Carlos Chávez

The impact of macroeconomics factors on real exchange rate in Latin America: A dynamic panel data analysis

Table 11: Im-Pesaran-Shin test for all transforms.

\begin{tabular}{|c|c|c|c|c|c|c|c|c|}
\hline Transform & $\begin{array}{c}\text { ADF } \\
\text { Statistics }\end{array}$ & $\begin{array}{c}\text { Gross } \\
\text { Domestic } \\
\text { Product } \\
\end{array}$ & $\begin{array}{l}\text { Consumer } \\
\text { Price Index }\end{array}$ & $\begin{array}{c}\text { Deposit } \\
\text { Interest } \\
\text { Rate } \\
\end{array}$ & $\begin{array}{c}\text { Real } \\
\text { Exchange } \\
\text { Rate } \\
\end{array}$ & $\begin{array}{l}\text { Governme } \\
\text { nt Spend }\end{array}$ & $\begin{array}{l}\text { Broad } \\
\text { Money }\end{array}$ & $\begin{array}{l}\text { Trade (\%) } \\
\text { of GDP) }\end{array}$ \\
\hline \multirow{2}{*}{ At level } & $\begin{array}{c}\text { IPS } \\
\text { Statistics }\end{array}$ & $-2.535^{* * *}$ & -1.262 & $-2.329 * * *$ & $-2.426 * * *$ & $-2.020 * *$ & $-2.23 * * *$ & $-2.38 * * *$ \\
\hline & P-value & 0.002 & 0.996 & 0.000 & 0.001 & 0.016 & 0.001 & 0.000 \\
\hline \multirow{2}{*}{$\begin{array}{c}\text { First } \\
\text { difference }\end{array}$} & $\begin{array}{c}\text { IPS } \\
\text { Statistics }\end{array}$ & $-32.241 * * *$ & $-53.222^{* * *}$ & $-6.082^{* * *}$ & $-8.741 * * *$ & $-6.710^{* * *}$ & $-8.83 * * *$ & $-7.45^{* * *}$ \\
\hline & P-value & 0.000 & 0.000 & 0.000 & 0.000 & 0.000 & 0.000 & 0.000 \\
\hline \multirow{2}{*}{$\begin{array}{c}\text { Forward } \\
\text { Orthogonal } \\
\text { Deviations }\end{array}$} & $\begin{array}{c}\text { IPS } \\
\text { Statistics }\end{array}$ & -1.657 & -1.785 & $-3.125^{* * *}$ & $-2.588^{* * *}$ & $-2.064 * * *$ & $-2.28^{* * *}$ & $-2.67 * * *$ \\
\hline & P-value & 0.552 & 0.382 & 0.000 & 0.000 & 0.009 & 0.001 & 0.000 \\
\hline
\end{tabular}

* Significance at $1 \%$ level

** Significance at $5 \%$ level

*** Significance at $10 \%$ level 
Figure 2: Kernel Density (1980 - 2018)
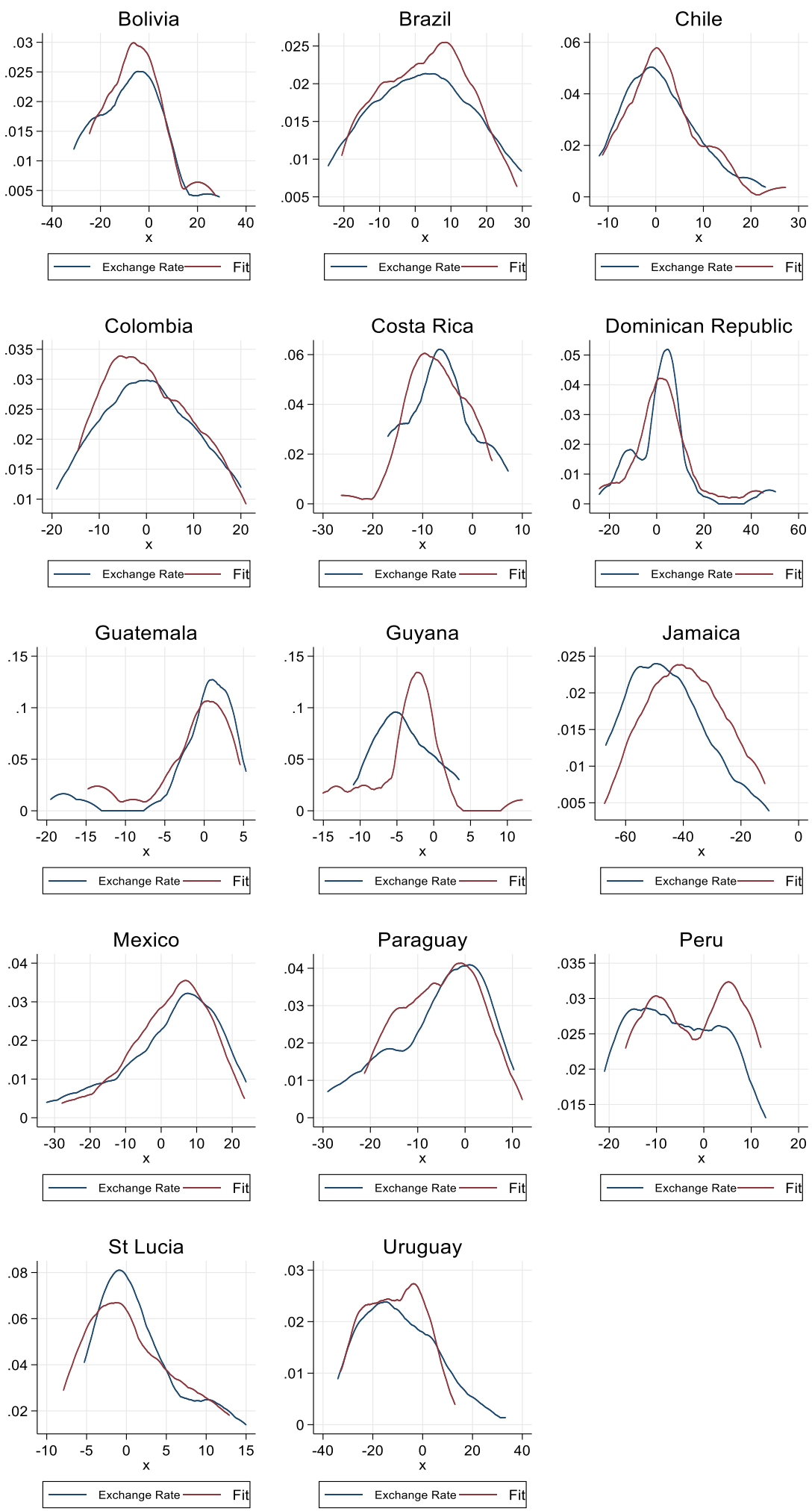

Sys Forward Orthogonal Devations GMM estimations 


\section{Carlos Chávez}

The impact of macroeconomics factors on real exchange rate in Latin America: A dynamic panel data analysis

\section{(c) (i) ()}

Open Access This article is licensed under a Creative Commons Atribution-Non Commercial 4.0 International License, which permits the use, adaption and sharing as long as you give appropriate credit to the original author(s) and the source. The images or other third party material in this article are included in the article's Creative Commons license, unless indicated otherwise in a credit line to the material. If materials are not included in the article's Creative Commons license and your intended use is not permitted by statutory regulation or exceeds the permitted use, you will need to obtain permission directly from the copyright holder.

To view a copy of this license, visit http://creativecommons.org/licenses/by-nc/4.0/.

(C) The Author(s) 2020. 